\title{
Characteristics of Newly Developed Extruded Products Supplemented with Plants in a Form of Microwave-Expanded Snacks
}

\author{
Katarzyna Lisiecka ${ }^{1}$ (D), Agnieszka Wójtowicz ${ }^{1, *(D)}$ and Marek Gancarz ${ }^{2}$ (D) \\ 1 Department of Thermal Technology and Food Process Engineering, University of Life Sciences in Lublin, \\ Głęboka 31, 20-612 Lublin, Poland; katarzyna.zelizko@gmail.com \\ 2 Institute of Agrophysics Polish Academy of Sciences, Doświadczalna 4, 20-290 Lublin, Poland; \\ m.gancarz@ipan.lublin.pl \\ * Correspondence: agnieszka.wojtowicz@up.lublin.pl
}

Citation: Lisiecka, K.; Wójtowicz, A.; Gancarz, M. Characteristics of Newly Developed Extruded Products Supplemented with Plants in a Form of Microwave-Expanded Snacks. Materials 2021, 14, 2791. https:// doi.org/10.3390/ma14112791

Academic Editor: Cédric Delattre

Received: 22 April 2021

Accepted: 21 May 2021

Published: 24 May 2021

Publisher's Note: MDPI stays neutral with regard to jurisdictional claims in published maps and institutional affiliations.

Copyright: (c) 2021 by the authors. Licensee MDPI, Basel, Switzerland. This article is an open access article distributed under the terms and conditions of the Creative Commons Attribution (CC BY) license (https:// creativecommons.org/licenses/by/ $4.0 /)$.

\begin{abstract}
The following research focuses on the possibility of applying fresh plant material as a carrot pulp to supplement newly developed extruded products in the form of pellets and microwaveexpanded snacks. Fresh carrot pulp, as a valuable vegetable ingredient, was used in the amount of $2.5 \mathrm{~g} / 100 \mathrm{~g}$ to $30.0 \mathrm{~g} / 100 \mathrm{~g}$ in a potato-based recipe. The snack pellets were processed via extrusioncooking, using a single-screw extruder with a plasticizing unit $\mathrm{L} / \mathrm{D}=18$, and the use of variable screw speeds. The produced pellets underwent microwave expansion to limit the fat content, so as to produce ready-to-eat (RTE) snacks. The pellets and snacks were tested for nutritional value, as well as for selected quality features: physical properties, structure, pasting characteristics, and texture profile, and PCA analysis and a correlation matrix were performed on the obtained results. Microwave expansion of pellets increased the total phenolic content, the antioxidant activity, water absorption index and lightness of snacks, but decreased the bulk density and setback values of the expanded products when compared to pellets. Generally, we found that it was possible to use up to $30.0 \mathrm{~g} / 100 \mathrm{~g}$ of fresh carrot pulp with a positive effect on nutritional value, and without negative effects on the physical properties of extruded products. Both the extrusion-cooking and microwave expansion can minimize the negative impact on plant materials, due to the short processing time.
\end{abstract}

Keywords: plant material; fresh carrot; extrusion-cooking; microwave expansion; snacks; physical properties; color; texture

\section{Introduction}

Plant materials are recognized as the most important sources of the nutritional components that are necessary in the daily human diet [1]. Among the positive characteristics of plants, their antioxidant properties are the most underestimated [2]. Indeed, the extracted and concentrated biologically active compounds from plants can have an impact on the prevention or help of many pathological conditions [3].

Carrots are a valuable source of carotenoids and fiber [1]. A diet rich in dietary fiber prevents the occurrence of diabetes, esophageal hernia, obesity, etc. [4]. This vegetable is also an extremely important source of vitamin $A$, due to the presence of $\beta$-carotene [5]. Additionally, carrots are rich in vitamins $\mathrm{C}, \mathrm{B}_{1}, \mathrm{~B}_{2}, \mathrm{~B}_{6}$, and $\mathrm{B}_{9}$ as well as the mineral components, calcium, magnesium and phosphate. The carotenoids of carrots, in possessing antioxidant properties, contribute to cancer and cardiovascular disease prevention [6,7]. Moreover, the consumption of carrots is recognized for decreasing cholesterol levels, and positively influencing the whole-body condition [1,8]. Vitamin $C$ prevents infection and supports the absorption of non-heme iron. $\mathrm{B}_{1}$ has a positive influence on the nervous system, while $B_{2}$ is necessary for cellular respiration and the formation of red blood cells. Vitamins $B_{6}$ and $B_{9}$ protect against disease and heart attacks [8]. The overall vitamins and 
minerals provided by the consumption of carrots also reduce the risk of chronic diseases, cancer and stroke [9]. Therefore, fresh carrot pulp could be a potential nutritionally valuable additive for enhancing the nutritive value of snack foods. This is especially relevant today, when consumers are looking for healthier alternatives with pro-health properties to traditional snack foods [10].

Extrusion-cooking is an economic HTST (high temperature-short time) processing technique that is used in the manufacture of a wide range of cereal- and pulse-based processed puffed foods [11]. As an alternative to ready-to-eat (RTE) extrudates, thirdgeneration half product snack pellets are usually generated through so-called cold extrusion. Such pellets require an extra manufacturing step after pressure-thermal treatment, that is, they must undergo an expansion process. Traditionally, pellets are expanded by frying in deep oil, but other expansion methods have become more popular, i.e., hot air toasting or microwave heating to limit the fat content in RTE snacks [12].

The properties of extruded snack pellets, with the addition of fresh carrot pulp, expanded by microwaving has not yet been subject to study. Plant material such as fresh carrot pulp seems to be a valuable source of biologically active components, as well as a natural colorant. Moreover, as was assumed by Lisiecka and Wójtowicz [13], the application of fresh vegetable pulp is an efficient method to limit water and energy requirements during processing. Therefore, the present study is aimed at investigating the influence of the addition of varied fresh carrot content and variable screw speeds during processing on selected features of newly developed pellets and microwave-expanded snacks.

\section{Materials and Methods}

The basic raw materials were potato flakes (PF), potato grits (PG) and potato starch (PS,) provided by Pol-Foods Sp. z o. o. (Prostki, Poland). Ordinary carrot (Daucus carota) was bought at the local market in Lublin, Poland. The carrots were carefully washed with tap water, dried using paper towels, and ground by employing an LMN-100 laboratory knife mill TestChem (Radlin, Poland) for granulation below $1 \mathrm{~mm}$, to achieve fresh carrot pulp (FCP). The moisture content of all raw materials was checked according to Lisiecka and Wójtowicz [13].

\subsection{Pellet and Snack Preparation}

The composition of the control sample was $25 \mathrm{~g} / 100 \mathrm{~g}$ potato flakes, $25 \mathrm{~g} / 100 \mathrm{~g}$ potato grits, and $50 \mathrm{~g} / 100 \mathrm{~g}$ potato starch, according to the recipe. Other blends were supplemented with fresh carrot pulp (FCP) at a range varying from $2.5 \mathrm{~g} / 100 \mathrm{~g}$ to $30.0 \mathrm{~g} / 100 \mathrm{~g}$. The vegetable additive replaced the normal amount of potato starch in the prepared blends. All components were ground together, utilizing a laboratory knife mill with $0.4 \mathrm{~mm}$ sieve openings, to achieve blends with a particle size below $400 \mu \mathrm{m}$ before processing. The final moisture content of each blend (33\%) was obtained by spraying the blended components with the appropriate amount of tap water and then mixing for $15 \mathrm{~min}$. The amount of water was calculated based on the water content in all blend components, as described by Lisiecka and Wójtowicz [13], and thus, the application of fresh plant material significantly limited the water needed for processing.

The blends were extruded by using a single-screw extruder type TS-45 (ZMCh Metalchem, Gliwice, Poland) with a plasticizing unit profile of $\mathrm{L} / \mathrm{D}=18$, which incorporated an intensive glycol cooling section (Figure 1). The temperature range in the individual extruder sections was as follows: dosing section, $80-85^{\circ} \mathrm{C}$; plasticizing section, $90-105^{\circ} \mathrm{C}$; cooling section, $50-65{ }^{\circ} \mathrm{C}$; forming die, $60-75{ }^{\circ} \mathrm{C}$. Screw speeds ranging from $60 \mathrm{rpm}$ to $100 \mathrm{rpm}$ were applied to obtain snack pellets. The pellets were shaped as a dough strip using a $30 \times 0.4 \mathrm{~mm}$ flat forming die, and then cut to approx. $30 \times 30 \mathrm{~mm}$ squares. The extruded snack pellets were dried in a laboratory shelf dryer at $40^{\circ} \mathrm{C}$ by $10 \mathrm{~h}$ until the moisture content reached $11 \%$. The dried pellets were subsequently placed in sealed foil bags and stored until the final processing. The pellets were expanded to ready-to-eat 
(RTE) snacks by microwave treatment (AVM-914/WH Philips/Whirlpool, Sweden). The power of the microwave was $750 \mathrm{~W}$, and the optimal time of treatment (40 s) was selected experimentally.

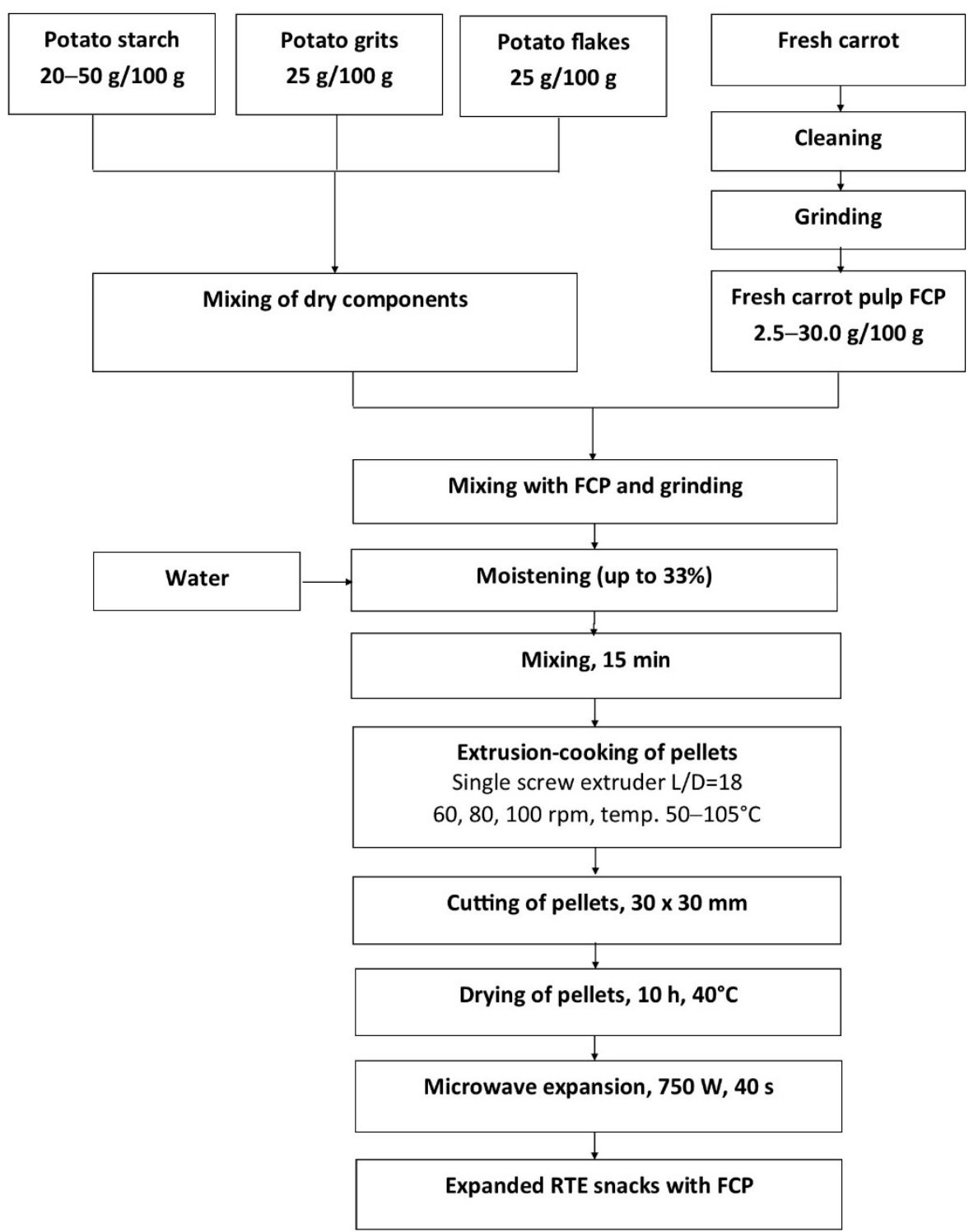

Figure 1. Diagram of the production process of pellets and snacks.

\subsection{Chemical Properties}

\subsubsection{Solvent Extraction Procedure}

Ground pellets or expanded snacks $(0.5 \mathrm{~g})$, with a granulation below $300 \mu \mathrm{m}$, were extracted in double by using $5 \mathrm{~mL}$ of $50 \%$ methanol (Avantor Performance Materials, Gliwice, Poland). The resulting extracts were shaken with a Multi RS-60 rotator (Biosan, Riga, Latvia) operating at $4200 \times g$ by $30 \mathrm{~min}$. The homogenate was then centrifuged using a T24D-type centrifuge (Medizintechnik, Leipzig, Germany) at $4200 \times g$ for $10 \mathrm{~min}$ at $4{ }^{\circ} \mathrm{C}$. The collected supernatants of methanol extracts were used for further analysis [14].

\subsubsection{Total Phenolic Content (TPC)}

Analysis of the total phenolic content in samples was prepared according to Singleton et al. [15], modified by Lisiecka et al. [16]. Here, $0.05 \mathrm{~mL}$ of $50 \%$ methanol, $0.1 \mathrm{~mL}$ of $\mathrm{H}_{2} \mathrm{O}$ and $0.4 \mathrm{~mL}$ of Folin-Ciocalteu reagent (at a ratio of 1:5 with distilled water) was mixed with the $0.05 \mathrm{~mL}$ of extract. After $3 \mathrm{~min}, 2 \mathrm{~mL}$ of $10 \%$ sodium carbonate 
was added to the mixture and shaken for $1 \mathrm{~min}$. Of note, $0.05 \mathrm{~mL}$ of the tested extract was replaced by $50 \%$ methanol in a reference sample. The absorbance was measured at $\lambda=725 \mathrm{~nm}$, using a spectrophotometer (Model 9423, Alt, GA, USA), and the results were expressed as gallic acid equivalents (GAE) in $\mathrm{mg} / \mathrm{g}$ of dry weight (d.w.).

\subsubsection{Scavenging Activity on 1,1-Diphenyl-2-picrylhydrazyl (DPPH) Radical}

In brief, in order to obtain a working solution, DPPH (1,1-diphenyl-2-picrylhydrazyl) radical was diluted in methanol to reach UV-VIS absorbance 0.7 at $515 \mathrm{~nm}$. Subsequently, $2.5 \mathrm{~mL}$ of DPPH radical, with a concentration of $0.2 \mathrm{mM}$, and $0.1 \mathrm{~mL}$ of the sample were mixed and kept for $30 \mathrm{~min}$ in a dark place, before measurement via spectrophotometer (Model 9423, Alt, GA, USA). Scavenging activity was calculated by using the formula according to Oniszczuk et al. [17], based on the method of Blois [18].

\subsection{Physical Properties}

\subsubsection{Bulk Density, Volumetric Expansion Index and Structure}

The bulk density (BBD) was specified as the mass of the sample, divided by the occupied volume of the cylinder (Lisiecka \& Wójtowicz, 2019) [19]. The volumetric expansion index (VEI) was calculated as the ratio of the density of pellets and snacks after expansion. The pellet and microwave-expanded snack structures were observed with an optical microscope (MBL3000T, mikroLAB, Poland), with magnification $\times 10$ for the surface and $\times 100$ for the cross-section.

\subsubsection{Water Absorption Index (WAI) and Water Solubility Index (WSI)}

$0.7 \mathrm{~g}$ of the sample was mixed with $7 \mathrm{~mL}$ of distilled water for $10 \mathrm{~min}$ and then centrifuged using a T24D-type centrifuge (Medizinetechnik, Leipzig, Germany) with a speed of $12,577 \times g$ for $10 \mathrm{~min}$. The gel was then separated from the filtrate. The water absorption index (WAI) was calculated as the ratio of gel weight to the weight of the dry sample. The filtrate was dried at $110^{\circ} \mathrm{C}$ until the water had completely evaporated. Water solubility index (WSI) was determined as the ratio of solids by weight in the supernatant after drying to the dry weight of the sample. WAI and WSI were expressed in $\mathrm{g} / \mathrm{g}$ and $\%$, respectively [20].

\subsubsection{Color Measurements}

The color profile was evaluated using an NR20XE Large Aperture Precision Colorimeter (Shiyan, Shenzhen, China). The color coordinates in the CIE-Lab scale indicated $L^{*}$, $a^{*}$ and $b^{*}$ described the brightness from 0 to 100 , the balance between redness $(+)$ and greenness $(-)$, and the balance between blueness $(-)$ and yellowness $(+)$, respectively. The $\Delta E$ was calculated as the total color change index [10].

\subsection{Pasting Properties}

The pasting properties of pellets and snacks were tested as described by Mitrus et al. [21], using the Brabender Micro Visco-Amylo-Graph (Brabender GmbH \& Co. KG, Duisburg, Germany). Accordingly, $10 \mathrm{~g}$ of the ground sample was dispersed in $100 \mathrm{~mL}$ of distilled water. The experiment was conducted at a speed of $250 \mathrm{rpm}$ and a sensitivity of $235 \mathrm{cmg}$. During all measurements, the following test profile was used: heating $\left(30-93^{\circ} \mathrm{C}\right)$ with a temperature gradient of $7.5^{\circ} \mathrm{C} / \mathrm{min}$, holding $\left(93^{\circ} \mathrm{C}\right.$ for $\left.5 \mathrm{~min}\right)$, cooling $\left(93-50^{\circ} \mathrm{C}\right)$ with a temperature gradient of $7.5^{\circ} \mathrm{C} / \mathrm{min}$, holding at $50^{\circ} \mathrm{C}$ for $1 \mathrm{~min}$. Selected pellet or expanded snack characteristics that were assessed included: peak viscosity (PV); hot paste viscosity (HPV); cold paste viscosity (CPV); breakdown (BD) as the difference between PV and HPV; and setback (SB) as the difference between $\mathrm{CPV}$ and $\mathrm{HPV}$, using the Brabender Viscograph software (version 4.1.1) application. 


\subsection{Texture Measurements}

Textural characteristics were examined using a Zwick/Roell BDO-FB0.5TH (Zwick $\mathrm{GmbH} \& \mathrm{Co} . \mathrm{KG}$, Ulm, Germany) testing machine equipped with a $0.5 \mathrm{kN}$ working head. The cutting force (CF) of the pellets was evaluated using a Warner-Bratzler shear device with a cutting test speed of $500 \mathrm{~mm} / \mathrm{min}$. Texture measurements of the microwaveexpanded snacks were determined a maximum of $10 \mathrm{~min}$ after expansion using the same apparatus, with a compression test undertaken via the use of a Kramer shear cell with a working head test speed of $100 \mathrm{~mm} / \mathrm{min}$, until the snack was completely broken down. Hardness $(\mathrm{H})$ was determined as the highest peak generated by the software during compression. Crispness (CR) was evaluated as the difference of force between the first significant peak force and the first minimum force following the first peak. Fracturability (F) was the first significant force peak during the compression cycle [22].

\subsection{Statistical Analysis}

Statistical analysis of the results was completed using Statistica 13.3 software (StatSoft, Tulsa, OK, USA). Response surface methodology was used to show the effect of multiple variables using a second-order polynomial model [5]. Homogeneous groups were determined by ANOVA using the Tukey post-hoc test at $\alpha=0.05$. The correlation matrix was formed of dependent features and by grouping variables using Pearson's coefficients. The similarity of pellets and snacks in terms of their analyzed features was based on principal component analysis (PCA). The PCA data matrix for the statistical analyses of the pellet results had 15 columns and 21 rows. However, the PCA data matrix for the statistical analyses of the results obtained for the snacks had 17 columns and 21 rows. The input matrix was scaled automatically. The correct number of main components obtained in the analysis was determined based on Cattell's criterion.

\section{Results and Discussion}

\subsection{Total Phenolic Content (TPC) and Antioxidant Activity of Snacks}

The release of phenolic acids can be related either to the selective heating of a number of individual phenolic acid compounds in the microwave field, or to the physical forces acting between the phenolic acids and the plant matrix [23]. Table 1 shows the total content of phenolic compounds (TPC), as well as the antioxidant activity (AA) of pellets and of the microwave-expanded snacks supplemented with plant material.

We saw that the microwave treatment increased the total content of polyphenols (at least by $33 \%$ ) and the ability to scavenge free radicals (increased by at least $47 \%$ ) in snacks compared to pellets. However, an insignificant effect of increased screw speed applied during the processing of samples was observed with the same amount of fresh carrot pulp, both for pellets and expanded snacks. Additionally, there was a positive correlation between the content of the additive and of the TPC and the AA in pellets $(r=0.97$ and 0.91) and snacks $(r=0.91$ and 0.94$)$, respectively. A strong positive correlation was also noted between the TPC of pellets and the TPC of snacks $(r=0.91)$, and between the TPC of snacks and the ability to scavenge free radicals in snacks $(r=0.94)$. Furthermore, it was noticed that the addition of fresh carrot pulp in the amount of $10.0 \mathrm{~g} / 100 \mathrm{~g}$ and $20.0 \mathrm{~g} / 100 \mathrm{~g}$ of pellets, as well as of $30.0 \mathrm{~g} / 100 \mathrm{~g}$ and $7.5 \mathrm{~g} / 100 \mathrm{~g}$ in the case of microwave-expanded snacks, significantly influenced the TPC and DPPH values, respectively, in comparison with the control sample. It is likely that microwave energy was efficiently delivered to materials by interacting with the electromagnetic field, providing rapid energy transfer. This effect can cause structural and morphological changes to plant tissues, making them more accessible to solvent extraction [24,25]. 
Table 1. Total phenolic content and antioxidant activity of pellets and microwave-expanded snacks supplemented with fresh carrot pulp.

\begin{tabular}{|c|c|c|c|c|c|}
\hline \multirow{2}{*}{$\begin{array}{l}\text { Amount of Carrot } \\
\qquad(\mathrm{g} / 100 \mathrm{~g})\end{array}$} & \multirow{2}{*}{$\begin{array}{l}\text { Screw Speed } \\
(\mathrm{rpm})\end{array}$} & \multicolumn{2}{|c|}{$\begin{array}{c}\text { TPC }^{1} \\
(\mathrm{mg} \mathrm{GAE} / 100 \mathrm{~g})\end{array}$} & \multicolumn{2}{|c|}{$\begin{array}{c}\mathrm{DPPH}^{2} \\
(\%)\end{array}$} \\
\hline & & $\mathbf{P}$ & S & $\mathbf{P}$ & $\mathbf{S}$ \\
\hline \multirow{3}{*}{0} & 60 & $58.88 \pm 1.07^{\mathrm{a}}$ & $127.52 \pm 3.62^{a b}$ & $6.89 \pm 0.56^{a}$ & $19.78 \pm 0.34^{a}$ \\
\hline & 80 & $61.65 \pm 1.71^{a b c}$ & $127.09 \pm 3.20^{a b}$ & $6.61 \pm 0.70^{\mathrm{a}}$ & $19.74 \pm 1.39^{\mathrm{a}}$ \\
\hline & 100 & $59.73 \pm 0.64^{\mathrm{ab}}$ & $124.54 \pm 0.64^{\mathrm{a}}$ & $6.65 \pm 0.74^{\mathrm{a}}$ & $19.50 \pm 0.26^{\mathrm{a}}$ \\
\hline \multirow{3}{*}{2.5} & 60 & $61.86 \pm 1.49 \mathrm{abcd}$ & $128.37 \pm 2.77^{a b}$ & $8.79 \pm 0.91^{\mathrm{ab}}$ & $23.31 \pm 0.20^{\mathrm{ab}}$ \\
\hline & 80 & $62.72 \pm 0.64 \mathrm{abcd}$ & $129.23 \pm 2.77^{a b}$ & $9.70 \pm 0.70 \mathrm{ab}$ & $25.29 \pm 1.65^{\mathrm{ab}}$ \\
\hline & 100 & $64.21 \pm 2.13^{\mathrm{abcd}}$ & $130.29 \pm 2.56^{\mathrm{ab}}$ & $8.02 \pm 0.28^{a b}$ & $24.88 \pm 1.09 \mathrm{ab}$ \\
\hline \multirow{3}{*}{5.0} & 60 & $66.55 \pm 0.21^{\text {abcdef }}$ & $130.72 \pm 2.13^{a b c}$ & $8.42 \pm 0.72 \mathrm{ab}$ & $23.72 \pm 1.16^{\mathrm{ab}}$ \\
\hline & 80 & $66.34 \pm 2.13^{\text {abcde }}$ & $133.28 \pm 2.55^{a b c}$ & $6.82 \pm 0.35^{\mathrm{a}}$ & $24.30 \pm 0.58^{\mathrm{ab}}$ \\
\hline & 100 & $67.19 \pm 1.28^{\text {bcdef }}$ & $134.56 \pm 2.13^{a b c}$ & $7.14 \pm 0.32^{\mathrm{a}}$ & $24.01 \pm 0.29 \mathrm{ab}$ \\
\hline \multirow{3}{*}{7.5} & 60 & $69.54 \pm 0.64$ def & $136.05 \pm 4.05^{\mathrm{abc}}$ & $6.75 \pm 0.56^{\mathrm{a}}$ & $29.73 \pm 0.89^{b c}$ \\
\hline & 80 & $68.05 \pm 0.85^{\text {cdef }}$ & $134.13 \pm 2.56^{a b c}$ & $6.47 \pm 0.98^{\mathrm{a}}$ & $30.17 \pm 0.44^{b c d}$ \\
\hline & 100 & $68.68 \pm 0.21^{\text {cdef }}$ & $134.98 \pm 2.13^{a b c}$ & $7.63 \pm 0.25^{\mathrm{a}}$ & $30.06 \pm 0.11^{b c d}$ \\
\hline \multirow{3}{*}{10.0} & 60 & $74.23 \pm 1.49$ fgh & $133.92 \pm 3.62^{a b c}$ & $7.17 \pm 0.56^{\mathrm{a}}$ & $37.44 \pm 0.82$ ef \\
\hline & 80 & $74.01 \pm 0.85^{\mathrm{efgh}}$ & $134.56 \pm 2.12 \mathrm{abc}$ & $7.67 \pm 0.07^{a}$ & $36.83 \pm 0.48$ cde \\
\hline & 100 & $72.95 \pm 0.64 \mathrm{efg}^{\mathrm{efg}}$ & $141.38 \pm 1.71^{a b c}$ & $7.07 \pm 0.60^{a}$ & $36.95 \pm 0.12$ de \\
\hline \multirow{3}{*}{20.0} & 60 & $78.92 \pm 1.92 \mathrm{gh}$ & $141.80 \pm 3.84 \mathrm{abc}$ & $11.32 \pm 0.77^{b}$ & $43.52 \pm 2.12$ efg \\
\hline & 80 & $79.34 \pm 1.49 \mathrm{gh}$ & $142.23 \pm 2.98^{b c}$ & $19.67 \pm 0.97^{\mathrm{cd}}$ & $37.07 \pm 0.24 \mathrm{de}$ \\
\hline & 100 & $80.41 \pm 1.71$ ghi & $140.31 \pm 2.77^{a b c}$ & $17.18 \pm 0.67^{\mathrm{c}}$ & $39.15 \pm 2.20$ ef \\
\hline \multirow{3}{*}{30.0} & 60 & $81.48 \pm 2.34$ hij & $147.56 \pm 1.92^{\mathrm{cd}}$ & $22.90 \pm 0.53^{\mathrm{d}}$ & $49.48 \pm 2.71^{g}$ \\
\hline & 80 & $88.08 \pm 0.43^{\mathrm{ij}}$ & $160.56 \pm 3.84 \mathrm{de}$ & $20.17 \pm 0.73^{\mathrm{cd}}$ & $44.34 \pm 1.02 \mathrm{fg}$ \\
\hline & 100 & $88.72 \pm 1.07^{\mathrm{j}}$ & $171.01 \pm 4.05^{\mathrm{e}}$ & $20.54 \pm 0.37 \mathrm{dc}$ & $47.27 \pm 2.20 \mathrm{~g}$ \\
\hline
\end{tabular}

TPC—total phenolic content; DPPH—antioxidant activity against DPPH radical; P-pellet; S—snack; ${ }^{1}$-means of 3 replications, ${ }^{2}$-means of 2 replications; ${ }^{a-j}$-means indicated with similar letters in columns do not differ significantly at $\alpha=0.05$.

Reports exist in the literature about microwave-expanded corn pellets with orange and powdered milk additions, in which an increase in total polyphenols after microwave treatment at $1450 \mathrm{~W}$ has been described [26]. Hayat et al. [23] also observed an increase in the content of polyphenols, and an enhancement of the antioxidant properties of extracts made from the citrus mandarin peel, after microwave treatment. Both groups of researchers noticed that the microwave power and the treatment time affected the phytochemical properties. Here, increased power and elongated time were found to be responsible for the degradation of some phenolic compounds. In contrast, the increase in antioxidant activity that corresponded with the increase in exposure time and microwave power can be attributed to the increase in free phenolic compound fractions-which demonstrate a greater antioxidant effect than do the bounded forms.

\subsection{Physical Properties}

The bulk density (BBDp) of the tested pellets and expanded snacks (BBDs), and the volumetric expansion index (VEI), are shown in Figure 2. In the case of pellets, an increase in BBD was noticed with the increase in screw speed at each level of the fresh carrot pulp addition. The range of the pellets' BBDp was from $236.04 \mathrm{~kg} / \mathrm{m}^{3}$ (pellets with $30.0 \mathrm{~g} / 100 \mathrm{~g}$ of additive content at minimum rpm) to $466.48 \mathrm{~kg} / \mathrm{m}^{3}$ (control sample at maximum rpm). Snacks expanded by the microwaving of these pellets were characterized by the smallest and the highest values of the expansion index, respectively (Figure 2c), but the differences were small, and insignificant differences were found depending on both the vegetable content and the screw speed applied during extrusion. It suggests a similar expansion of vegetable supplemented snacks via microwaves, which was also confirmed by the results obtained for the texture profile of snacks. 
a)

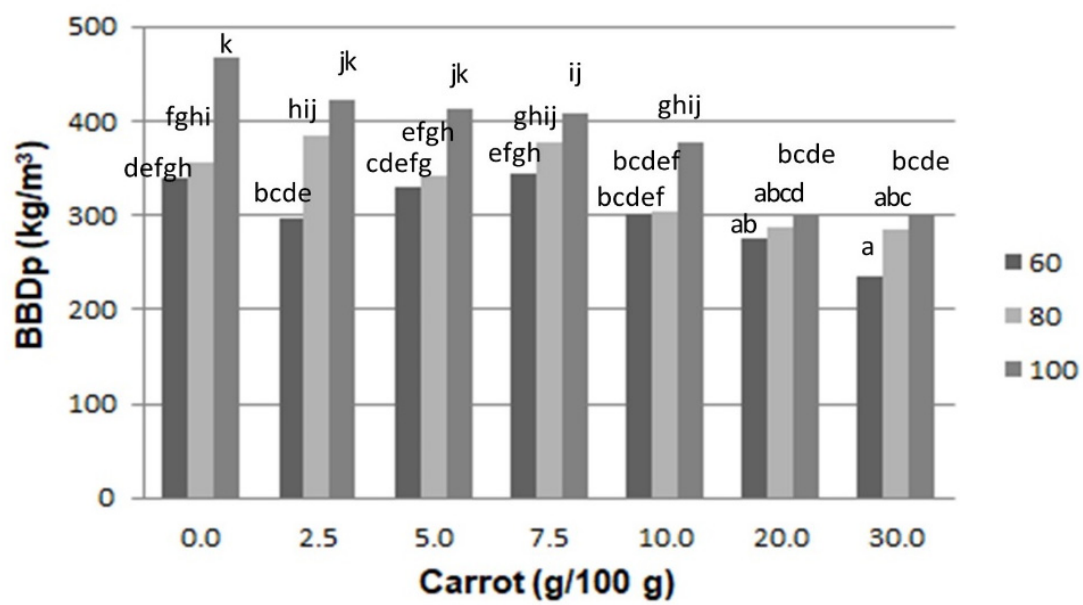

b)

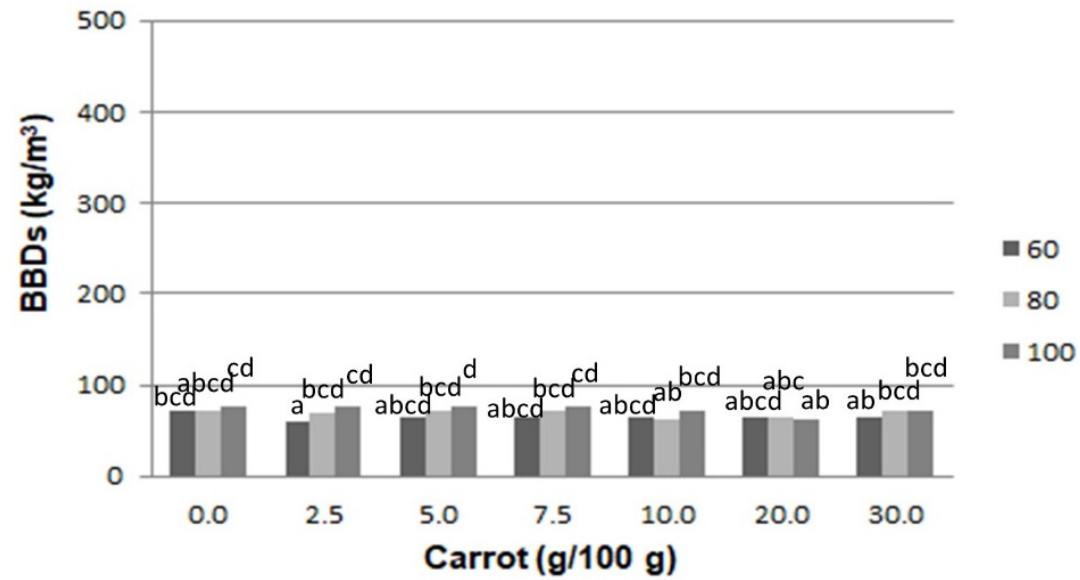

c)

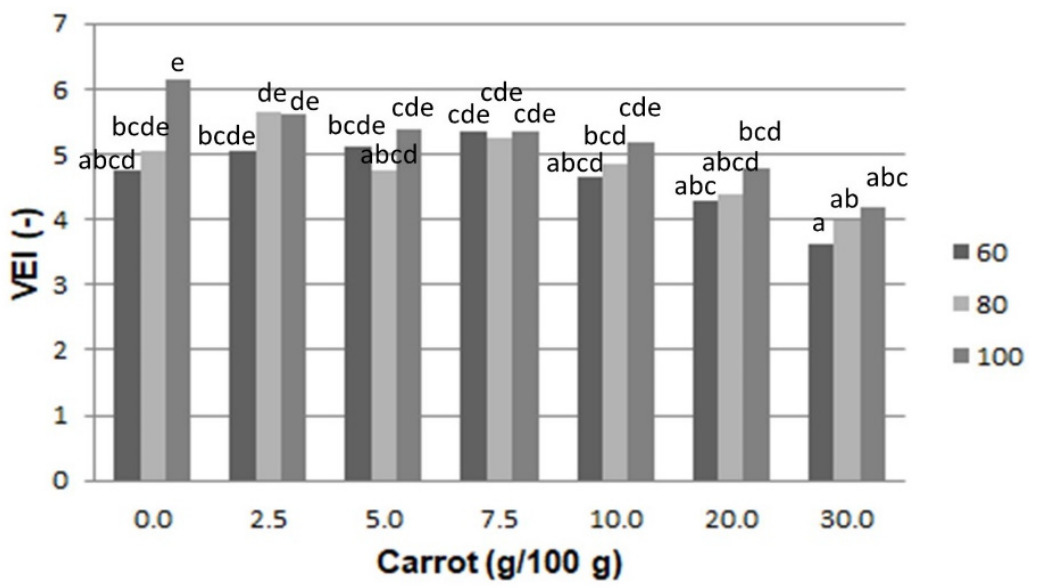

Figure 2. Results of the physical properties of extrudates supplemented with fresh carrot pulp, processed at variable screw speeds: (a) the bulk density of pellets, (b) the bulk density of snacks, (c) volumetric expansion index of snacks. ${ }^{\mathrm{a}-\mathrm{k}}$ - means indicated with similar letters in each figure do not differ significantly at $\alpha=0.05$.

As expected, there was a strong positive correlation between the pellets' density and the VEI $(r=0.90)$. A negative correlation, however, was observed between the amount of additive and the BBDp of pellets $(r=-0.71)$ and the VEI $(r=-0.83)$. On the other hand, a positive correlation was noted between the screw speed and the density of pellets and snacks $(r=0.58$ and 0.65 , respectively). The BBDp of pellets was also positively correlated with the density of the snacks $(r=0.74)$. Moreover, there were some significant differences 
found between the pellets' bulk density values between $60 \mathrm{rpm}$ and $100 \mathrm{rpm}$, except at the $20.0 \mathrm{~g} / 100 \mathrm{~g}$ level.

Microwave-expanded snacks with the addition of fresh carrot pulp had BBD values ranging from $58.79 \mathrm{~kg} / \mathrm{m}^{3}$ (snacks with $2.5 \mathrm{~g} / 100 \mathrm{~g}$ of carrot pulp at maximum rpm) to $76.93 \mathrm{~kg} / \mathrm{m}^{3}$ (snacks with $5 \mathrm{~g} / 100 \mathrm{~g}$ vegetable content at maximum screw speed). The bulk density of soybean-based RTE extrudates also increased with an increasing rotational screw speed during extrusion [27], because of the high temperature-induced starch gelatinization, which makes it possible to obtain snacks with a lower density despite the use of increasing $\mathrm{rpm}$, as shown by the production of brown rice extrudates. The low density is influenced by the breakdown of the protein and starch matrix under high shear forces [28]. Since the production of third-generation expanded snacks from starchy pellets involves the use of lower temperatures to avoid the boiling of the water present in the raw materials, and thus the direct expansion of the pellet strip, this outcome is most likely connected with the higher density and viscosity of the dough at increased applied rpm during processing, as is indicated by significant differences in the pellets' bulk density when processed at the lowest and the highest screw speeds (Figure 2a).

Figure 3 shows the structure of fresh carrot pulp-supplemented pellet surfaces $(\times 10$ magnification), and cross-sections of the microwave-expanded snacks $(\times 100$ magnification), respectively. Microscopic observations confirmed the compact and glassy surface of pellets, indicating a good gelatinization of the extruded samples. Such an effect became more evident as the carrot pulp addition increased, and with this increase, vegetable particles could be seen on the surfaces and in inside the structures of the extruded pellets. Pellets processed at a higher screw rpm were less smooth on the surface, especially when high amounts of vegetables were added, as shown in Figure 3. On observing the cross-section of microwave-expanded snacks, we found a porous inside structure with empty cells that increased in quantity, yet had dimensions that decreased in size with the increased level of fresh carrot pulp in the recipe. Nevertheless, all the tested snack pellets supplemented with fresh carrot pulp successfully underwent microwave expansion. This increased level of vegetable additive made the inside structure denser and limited cell size, as was confirmed by the VEI results.

The WAI measures the amount of water absorbed by the starch and can be used as an indicator of the degree of starch gelatinization. The WSI value describes the degradation of molecular components after technological treatment, which is measured by the amount of soluble polysaccharides released from the product, and indicates the degree of starch conversion during the extrusion-cooking process [28]. Table 2 presents the values of the WAI and WSI for the tested pellets and microwave-expanded snacks. The maximum value of WAI for pellets and snacks was $4.90 \mathrm{~g} / \mathrm{g}$ and $5.61 \mathrm{~g} / \mathrm{g}$, respectively, for pellets with $5.0 \mathrm{~g} / 100 \mathrm{~g}$ of fresh carrot pulp content extruded at $80 \mathrm{rpm}$ and for expanded snacks with $20.0 \mathrm{~g} / 100 \mathrm{~g}$ of additive, processed at maximum screw speed. A minimum WAI value was observed for pellets with $7.5 \mathrm{~g} / 100 \mathrm{~g}$ of vegetable content, and snacks with $30.0 \mathrm{~g} / 100 \mathrm{~g}$ of the additive, processed at the lowest rpm. However, a significant difference in the WAI value was only noticed in the extreme values of the pellets, compared to their controls, produced at identical rpm. The WSI values ranged from $1.42 \%$ to $5.69 \%$ for pellets produced at $60 \mathrm{rpm}$, with the addition of $5.0 \mathrm{~g} / 100 \mathrm{~g}$ and $30.0 \mathrm{~g} / 100 \mathrm{~g}$ of fresh carrot pulp, respectively. The microwave treatment increased the WSI of the snacks, compared to the pellets. The WSI of the supplemented snacks ranged from $2.34 \%(5.0 \mathrm{~g} / 100 \mathrm{~g}$ of carrot processed at $80 \mathrm{rpm})$, to $10.48 \%(20.0 \mathrm{~g} / 100 \mathrm{~g}$ snacks extruded at $100 \mathrm{rpm})$. At the same time, it was noticed that the maximum WSI values of the sample of pellets and snacks differed significantly from the other samples containing less than $7.5 \mathrm{~g} / 100 \mathrm{~g}$ and $20.0 \mathrm{~g} / 100 \mathrm{~g}$ of additive, respectively, which was not dependent on the rotational speed of the extruder screw. 

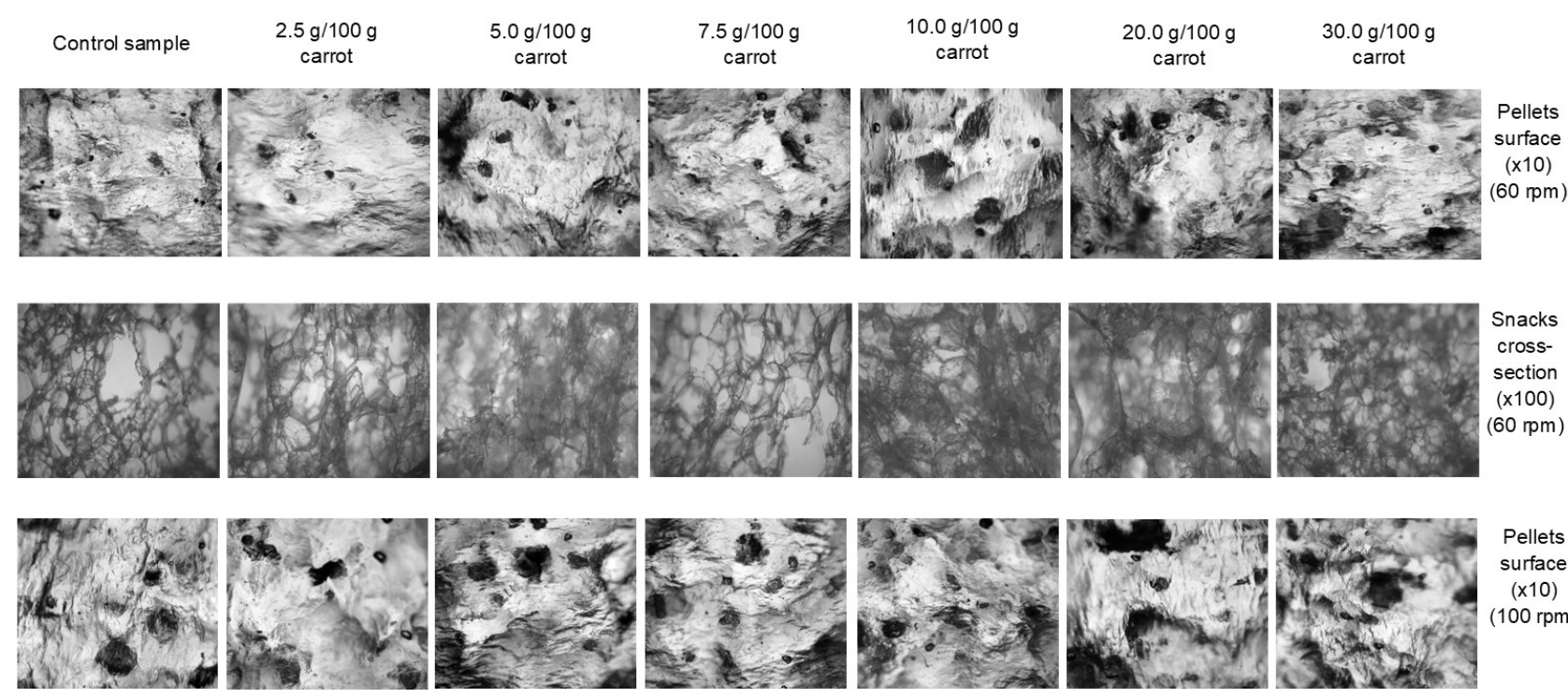

Pellets

surface

$(\mathrm{x} 10)$
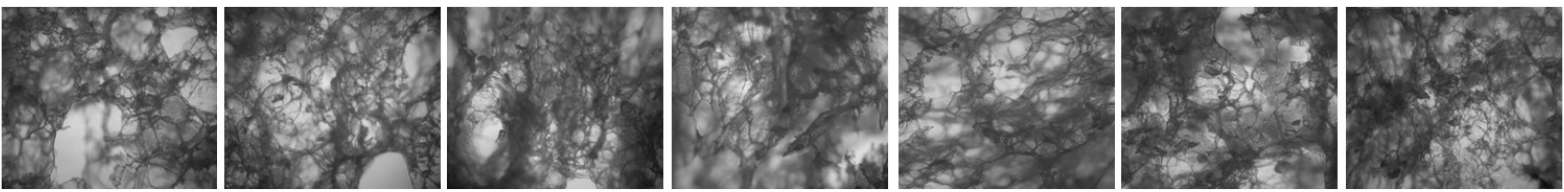

Snacks

cross-

section

$(\mathrm{x} 100)$

Figure 3. Microscopic structure of pellet and microwave-expanded snack surfaces ( $\times 10$ magnification), and cross-section ( $\times 100$ magnification). Herein, the structure depends on the content of the fresh carrot pulp addition (in columns) and screw speed during processing (in rows).

Table 2. Physical properties of pellets and microwave-expanded snacks with the addition of fresh carrot pulp.

\begin{tabular}{|c|c|c|c|c|c|}
\hline \multirow{2}{*}{$\begin{array}{l}\text { Amount of Carrot } \\
(\mathrm{g} / 100 \mathrm{~g})\end{array}$} & \multirow{2}{*}{$\begin{array}{l}\text { Screw Speed } \\
(\mathrm{rpm})\end{array}$} & \multicolumn{2}{|c|}{$\mathrm{WAI}^{1}(\mathrm{~g} / \mathrm{g})$} & \multicolumn{2}{|c|}{ WSI $^{1}(\%)$} \\
\hline & & $\mathbf{P}$ & $\mathbf{S}$ & $\mathbf{P}$ & $S$ \\
\hline \multirow{3}{*}{0} & 60 & $4.53 \pm 0.05^{\text {cdefgh }}$ & $4.82 \pm 0.26^{\mathrm{abc}}$ & $3.56 \pm 0.01$ abcdef & $4.32 \pm 0.69 \mathrm{abcd}$ \\
\hline & 80 & $4.37 \pm 0.06^{\text {cdef }}$ & $5.49 \pm 0.14^{\mathrm{cd}}$ & $2.76 \pm 0.28$ abcdef & $6.73 \pm 0.35$ defg \\
\hline & 100 & $3.85 \pm 0.04^{\mathrm{ab}}$ & $5.00 \pm 0.28^{\mathrm{abcd}}$ & $2.78 \pm 0.18^{\text {abcdef }}$ & $3.94 \pm 0.32^{\mathrm{abcd}}$ \\
\hline \multirow{3}{*}{2.5} & 60 & $4.51 \pm 0.10^{\text {cdefgh }}$ & $4.85 \pm 0.29 \mathrm{abcd}$ & $4.56 \pm 0.24^{\mathrm{fg}}$ & $5.54 \pm 1.31$ bcde \\
\hline & 80 & $4.65 \pm 0.02$ defgh & $4.54 \pm 0.16^{\mathrm{a}}$ & $1.77 \pm 0.34^{\mathrm{ab}}$ & $3.27 \pm 0.50^{a b}$ \\
\hline & 100 & $4.29 \pm 0.01^{\text {cde }}$ & $4.69 \pm 0.23^{\mathrm{ab}}$ & $1.99 \pm 0.69 \mathrm{abc}$ & $3.71 \pm 0.23^{a b c}$ \\
\hline \multirow{3}{*}{5.0} & 60 & $4.76 \pm 0.03^{\mathrm{fgh}}$ & $4.72 \pm 0.09^{a b}$ & $1.42 \pm 0.35^{\mathrm{a}}$ & $4.79 \pm 0.06^{\text {abcd }}$ \\
\hline & 80 & $4.90 \pm 0.03^{\mathrm{h}}$ & $4.53 \pm 0.02^{\mathrm{a}}$ & $1.91 \pm 0.40^{\mathrm{abc}}$ & $2.34 \pm 0.05^{\mathrm{a}}$ \\
\hline & 100 & $4.67 \pm 0.03^{\text {efgh }}$ & $5.43 \pm 0.37^{b c d}$ & $1.85 \pm 0.25^{a b c}$ & $4.11 \pm 0.10^{\mathrm{abcd}}$ \\
\hline \multirow{3}{*}{7.5} & 60 & $3.71 \pm 0.10^{\mathrm{a}}$ & $4.49 \pm 0.02^{\mathrm{a}}$ & $3.76 \pm 0.52^{\text {cdefg }}$ & $3.92 \pm 1.23^{\mathrm{abcd}}$ \\
\hline & 80 & $4.76 \pm 0.33 \mathrm{fgh}$ & $4.78 \pm 0.21 \mathrm{abc}$ & $2.83 \pm 0.22$ abcdef & $5.15 \pm 0.90$ abcde \\
\hline & 100 & $4.66 \pm 0.03^{\text {efgh }}$ & $4.98 \pm 0.11^{\mathrm{abcd}}$ & $2.55 \pm 0.24^{\text {abcdef }}$ & $4.99 \pm 0.20^{\mathrm{abcd}}$ \\
\hline \multirow{3}{*}{10.0} & 60 & $3.87 \pm 0.06^{\mathrm{ab}}$ & $4.70 \pm 0.30^{\mathrm{ab}}$ & $3.92 \pm 1.10^{\text {cdefg }}$ & $5.97 \pm 0.10$ bcde \\
\hline & 80 & $4.81 \pm 0.01 \mathrm{gh}$ & $4.79 \pm 0.17^{a b c}$ & $2.21 \pm 0.06^{\mathrm{abcd}}$ & $4.00 \pm 0.82^{\mathrm{abcd}}$ \\
\hline & 100 & $4.85 \pm 0.10 \mathrm{gh}$ & $4.60 \pm 0.04^{\mathrm{a}}$ & $2.68 \pm 0.34$ abcdef & $4.10 \pm 0.70^{\mathrm{abcd}}$ \\
\hline \multirow{3}{*}{20.0} & 60 & $4.25 \pm 0.08^{b c d}$ & $5.05 \pm 0.04^{\mathrm{abcd}}$ & $4.10 \pm 0.46^{\operatorname{defg}}$ & $6.19 \pm 0.19$ cdef \\
\hline & 80 & $4.34 \pm 0.24^{\text {cde }}$ & $5.05 \pm 0.14^{\mathrm{abcd}}$ & $2.41 \pm 0.69$ abcde & $8.83 \pm 0.24 \mathrm{fgh}$ \\
\hline & 100 & $4.55 \pm 0.12^{\text {cdefgh }}$ & $5.61 \pm 0.29 \mathrm{~d}$ & $2.70 \pm 0.58^{\text {abcdef }}$ & $10.48 \pm 1.57^{h}$ \\
\hline \multirow{3}{*}{30.0} & 60 & $4.15 \pm 0.05^{b c}$ & $4.45 \pm 0.27^{\mathrm{a}}$ & $5.69 \pm 0.91 \mathrm{~g}$ & $7.85 \pm 1.29$ efgh \\
\hline & 80 & $4.44 \pm 0.14^{\text {cdefg }}$ & $4.70 \pm 0.05^{\mathrm{ab}}$ & $3.46 \pm 1.27^{\text {abcdef }}$ & $9.28 \pm 0.10 \mathrm{gf}$ \\
\hline & 100 & $4.32 \pm 0.09$ cde & $4.53 \pm 0.15^{\mathrm{a}}$ & $4.48 \pm 0.27^{\text {efg }}$ & $5.34 \pm 0.86^{\text {bcde }}$ \\
\hline
\end{tabular}

WAI—water absorption index; WSI-water solubility index; $\mathrm{P}$ - pellet; S-snack; ${ }^{1}$-means of 3 replications; ${ }^{\text {a-h }}$-means indicated with similar letters in columns do not differ significantly at $\alpha=0.05$. 
According to the literature, the values of the WAI and WSI depend on two main variables. The first variable includes factors directly related to the properties of raw materials, their composition, the pre-treatment, and the method of their grinding. The second includes temperature, humidity, screw speed, configuration and compression ratio of the screw, and the dimension and configuration of the forming die [29]. In our study, a positive correlation was found between the amount of the additive and the WSI value of pellets and expanded snacks ( $r=0.53$ and 0.67 , respectively). The WSI index of pellets and snacks was also negatively correlated with the BBD results $(r=-0.59$ and -0.60 , respectively), as well as with the VEI ( $\mathrm{r}=-0.60$ for both products). In the case of WSI, there is a positive correlation between the WAI of pellets and snacks. Silva et al. [30] observed that low moisture content of extruded blends and high sucrose content lead to an increase in the WSI. The low molecular weight and the addition of sugars tended to increase the content of soluble solids. The unambiguous effects of both vegetable content in the recipe and screw speeds applied on WAI and WSI were observed, as confirmed by the indication of homogenous groups for these results.

Table 3 shows the values of the $L^{*}, a^{*}$, and $b^{*}$ coordinates, as well as the $\Delta E$ index of pellets and microwave-expanded snacks that have been supplemented with fresh carrot pulp. The microwave treatment increased the lightness of the expanded snacks in relation to the pellets, independently of the content of the additive and the screw speed applied during processing. This change in color was attributed to the loss of the compact structure and, hence, a change in light passing through the pellets after microwaving. Both the pellets and expanded snacks showed a greater redness and yellowness with the increase in the percentage of fresh carrot addition. The $\Delta E$ index revealed, however, that there were significant changes only in the color of the RTE snacks. We believe that the color of both pellets and snacks was affected by the carotenoids contained within the fresh carrot, used as an additive. Carotenoids contribute to the formation of red, orange and yellow colors [31]. However, in the literature, color changes are also attributed to browning reactions, e.g., caramelization, Maillard reactions, or pigment degradation, which sometimes accompany high-temperature treatment [32]. Moreover, the addition of fresh carrot pulp, which is rich in simple sugars, may also affect the intensity of browning during microwave heating if more of the vegetable was used.

The $L^{*}$ coordinate of the pellets showed a strong negative correlation with the amount of additive $(\mathrm{r}=-0.83)$, as well as with $a^{*}(\mathrm{r}=-0.87)$ and $b^{*}(\mathrm{r}=-0.80)$ pellet coordinates. It also showed a positive correlation with the VEI $(\mathrm{r}=0.89)$. Moreover, the $a^{*}$ coordinate of the pellets showed a strong positive correlation with the amount of additive $(r=0.97)$, and the pellet and expanded snack TPC ( $\mathrm{r}=0.97$ and 0.89 , respectively), as well as the AA of the pellets $(\mathrm{r}=0.84)$ and snacks $(\mathrm{r}=0.91)$, the $b^{*}$ coordinates of the pellets $(\mathrm{r}=0.85)$, and $a^{*}$ and $b^{*}$ values of the expanded snacks $(\mathrm{r}=0.90$ and 0.91 , respectively). In contrast, a negative coefficient was found between $a^{*}$ and VEI $(\mathrm{r}=-0.83)$. In addition, the $b^{*}$ coordinate of pellets was positively correlated with its counterpart, found in the expanded snacks $(r=0.80)$. The paleness of the microwave-expanded snacks was negatively related only to the redness of the snacks $(\mathrm{r}=-0.81)$. The $a^{*}$ and $b^{*}$ coordinates of supplemented snacks were, respectively, positively related to the amount of additive $(r=0.92$ and 0.91$)$, the TPC of pellets $(\mathrm{r}=0.92$ and 0.90$)$, the AA of snacks $(\mathrm{r}=0.92$ and 0.87$)$, and were strongly related to each other $(\mathrm{r}=0.97)$. Generally, it was noticed that the minimum $L^{*}$ values of the pellets with $30.0 \mathrm{~g} / 100 \mathrm{~g}$ of carrot extruded at $80 \mathrm{rpm}$ differed significantly from the other samples. In the case of the pellets, it was noticed that the addition of more than $5.0 \mathrm{~g} / 100 \mathrm{~g}$ of fresh carrot pulp significantly affected the value of the $a^{*}$ coordinate, while in the case of snacks, this relationship was already visible above $2.5 \mathrm{~g} / 100 \mathrm{~g}$. On the other hand, in the case of $b^{*}$, it was noted that the addition of more than $10.0 \mathrm{~g} / 100 \mathrm{~g}$ and $20.0 \mathrm{~g} / 100 \mathrm{~g}$ of fresh carrot pulp significantly influenced the $b^{*}$ coordinate value of pellets and snacks, respectively. Differences in color coordinates showed the unambiguous effects of screw speeds applied during the processing of samples, with the same amount of vegetable pulp added. 
Table 3. The color of pellets and microwave-expanded snacks with the addition of fresh carrot pulp.

\begin{tabular}{|c|c|c|c|c|c|c|c|c|c|}
\hline \multirow{2}{*}{$\begin{array}{c}\text { Amount of } \\
\text { Carrot }(\mathrm{g} / 100 \mathrm{~g})\end{array}$} & \multirow{2}{*}{$\begin{array}{c}\text { Screw } \\
\text { Speed (rpm) }\end{array}$} & \multicolumn{2}{|c|}{$L^{* 1}$} & \multicolumn{2}{|c|}{$a^{* 1}$} & \multicolumn{2}{|c|}{$b^{* 1}$} & \multicolumn{2}{|c|}{$\Delta E$} \\
\hline & & $\mathbf{P}$ & $\mathrm{S}$ & $\mathbf{P}$ & $\mathrm{S}$ & $\mathbf{P}$ & $\mathrm{S}$ & $\mathbf{P}$ & $\mathrm{s}$ \\
\hline \multirow{3}{*}{0} & 60 & $78.21 \pm 1.09$ defg & $84.03 \pm 0.63^{\text {cdefg }}$ & $5.74 \pm 0.29 \mathrm{abc}$ & $8.43 \pm 0.25^{a}$ & $26.51 \pm 0.58^{\mathrm{cd}}$ & $22.30 \pm 0.41 \mathrm{ab}$ & ref & ref \\
\hline & 80 & $81.98 \pm 1.78$ ghijk & $85.50 \pm 1.95^{f g}$ & $5.49 \pm 0.25 \mathrm{abc}$ & $8.17 \pm 0.20^{\text {a }}$ & $24.40 \pm 0.52^{a b c}$ & $21.52 \pm 0.50^{\mathrm{a}}$ & ref & ref \\
\hline & 100 & $85.06 \pm 2.52^{k}$ & $86.03 \pm 1.00^{f g}$ & $5.07 \pm 0.38^{\mathrm{ab}}$ & $8.36 \pm 0.10^{\mathrm{a}}$ & $22.22 \pm 0.76^{\mathrm{a}}$ & $21.95 \pm 0.19 \mathrm{ab}$ & ref & ref \\
\hline \multirow{3}{*}{2.5} & 60 & $81.67 \pm 0.75^{\text {ghijk }}$ & $85.93 \pm 1.45^{\mathrm{fg}}$ & $5.64 \pm 0.18 \mathrm{abc}$ & $8.44 \pm 0.11^{\text {a }}$ & $25.79 \pm 0.60 \mathrm{bcd}$ & $22.93 \pm 0.35^{b c}$ & 0.36 & 2.01 \\
\hline & 80 & $84.33 \pm 1.25^{\mathrm{jk}}$ & $85.13 \pm 1.16^{\text {efg }}$ & $4.81 \pm 0.18^{\text {a }}$ & $8.62 \pm 0.19^{\mathrm{ab}}$ & $23.61 \pm 0.41^{\mathrm{ab}}$ & $22.90 \pm 0.31$ bc & 0.54 & 1.50 \\
\hline & 100 & $80.81 \pm 1.37^{\text {fghij }}$ & $86.84 \pm 1.34 \mathrm{~g}$ & $6.20 \pm 0.43 \mathrm{bcd}$ & $8.72 \pm 0.25 \mathrm{ab}$ & $26.27 \pm 0.93 \mathrm{bcd}$ & $23.12 \pm 0.68^{\text {bcd }}$ & 1.17 & 1.46 \\
\hline \multirow{3}{*}{5.0} & 60 & $80.31 \pm 0.53$ efghi & $84.81 \pm 0.89$ defg & $6.54 \pm 0.17^{\mathrm{cd}}$ & $9.10 \pm 0.21 \mathrm{bc}$ & $27.28 \pm 1.02^{\mathrm{d}}$ & $23.79 \pm 0.42$ cde & 0.72 & 1.81 \\
\hline & 80 & $77.27 \pm 0.54^{\text {cdef }}$ & $84.44 \pm 1.71$ defg & $8.47 \pm 0.18^{\text {ef }}$ & $9.51 \pm 0.25^{\text {cde }}$ & $33.04 \pm 1.38^{\text {fgh }}$ & $24.45 \pm 0.39$ ef & 1.52 & 3.39 \\
\hline & 100 & $78.80 \pm 0.51$ defg & $85.67 \pm 0.73^{\mathrm{fg}}$ & $8.11 \pm 0.25^{\text {ef }}$ & $9.37 \pm 0.21^{\mathrm{cd}}$ & $30.64 \pm 0.29$ ef & $24.24 \pm 0.34^{\mathrm{de}}$ & 2.06 & 2.52 \\
\hline \multirow{3}{*}{7.5} & 60 & $80.23 \pm 1.36^{\text {efghi }}$ & $85.09 \pm 0.32$ efg & $7.42 \pm 0.32$ de & $9.16 \pm 0.09 \mathrm{bc}$ & $26.28 \pm 0.80^{\text {bcd }}$ & $24.20 \pm 0.16^{\mathrm{de}}$ & 0.35 & 2.30 \\
\hline & 80 & $83.06 \pm 0.755^{\mathrm{ijk}}$ & $83.98 \pm 1.38^{\text {bcdef }}$ & $7.29 \pm 0.35$ de & $10.53 \pm 0.19^{\mathrm{fg}}$ & $27.90 \pm 1.00$ de & $26.11 \pm 0.49$ gh & 1.14 & 5.75 \\
\hline & 100 & $82.74 \pm 2.77^{\text {hijk }}$ & $82.97 \pm 0.84$ bcdef & $7.43 \pm 0.55$ de & $9.42 \pm 0.19^{\mathrm{cd}}$ & $27.48 \pm 0.80^{\mathrm{d}}$ & $23.82 \pm 0.51$ cde & 0.30 & 3.74 \\
\hline \multirow{3}{*}{10.0} & 60 & $77.57 \pm 0.36^{\text {cdef }}$ & $82.16 \pm 0.76^{\text {abcde }}$ & $8.88 \pm 0.16^{\mathrm{fg}}$ & $9.84 \pm 0.07$ de & $31.35 \pm 0.84^{\mathrm{fg}}$ & $24.09 \pm 0.10^{\text {cde }}$ & 0.78 & 2.94 \\
\hline & 80 & $76.13 \pm 0.97 \mathrm{~cd}$ & $83.64 \pm 1.11^{\text {cdef }}$ & $10.04 \pm 0.62 \mathrm{~g}$ & $10.02 \pm 0.19$ ef & $31.27 \pm 0.74^{\mathrm{fg}}$ & $24.88 \pm 0.43^{\text {efg }}$ & 0.92 & 4.26 \\
\hline & 100 & $81.00 \pm 1.40^{\text {fghij }}$ & $81.72 \pm 0.96^{\mathrm{abcd}}$ & $8.21 \pm 0.70^{\text {ef }}$ & $9.93 \pm 0.29$ de & $25.79 \pm 2.57 \mathrm{bcd}$ & $23.88 \pm 0.58^{\text {cde }}$ & 2.16 & 4.97 \\
\hline \multirow{3}{*}{20.0} & 60 & $76.59 \pm 1.96^{\text {cde }}$ & $79.41 \pm 0.52^{\mathrm{a}}$ & $12.43 \pm 1.30^{\mathrm{hi}}$ & $10.99 \pm 0.26^{\text {gh }}$ & $33.43 \pm 1.77^{\mathrm{fg}}$ & $25.64 \pm 0.67^{\mathrm{fg}}$ & 1.79 & 6.25 \\
\hline & 80 & $78.89 \pm 0.56^{\text {defgh }}$ & $79.98 \pm 1.37^{\mathrm{ab}}$ & $11.74 \pm 0.53^{\mathrm{h}}$ & $11.05 \pm 0.14$ ghi & $31.97 \pm 0.70 \mathrm{fgh}$ & $26.14 \pm 0.39 \mathrm{gh}$ & 1.27 & 7.76 \\
\hline & 100 & $76.85 \pm 1.64^{\text {cde }}$ & $82.08 \pm 0.68$ abcde & $12.58 \pm 0.46$ hi & $11.45 \pm 0.13^{\text {hij }}$ & $32.93 \pm 0.74$ fgh & $27.18 \pm 0.42$ hi & 0.88 & 7.24 \\
\hline \multirow{3}{*}{30.0} & 60 & $70.46 \pm 2.25^{\mathrm{ab}}$ & $82.08 \pm 1.09$ abcde & $13.39 \pm 0.76^{\mathrm{ij}}$ & $11.75 \pm 0.43^{j}$ & $30.75 \pm 1.20^{\mathrm{fg}}$ & $27.48 \pm 1.15^{\mathrm{i}}$ & 1.40 & 6.45 \\
\hline & 80 & $69.23 \pm 1.29^{a}$ & $83.45 \pm 1.82^{\text {cdef }}$ & $16.09 \pm 0.39 \mathrm{~g}$ & $10.88 \pm 0.04^{\text {gh }}$ & $34.26 \pm 0.71^{\mathrm{h}}$ & $26.93 \pm 0.22^{\mathrm{hi}}$ & 0.55 & 6.39 \\
\hline & 100 & $73.95 \pm 2.33^{b c}$ & $81.06 \pm 1.97^{a b c}$ & $14.62 \pm 0.69^{j}$ & $11.59 \pm 0.45^{\mathrm{ij}}$ & $32.42 \pm 1.52 \mathrm{fgh}$ & $27.29 \pm 0.52^{\text {hi }}$ & 0.85 & 7.97 \\
\hline
\end{tabular}

$L^{*}$-lightness from 0 to $100 ; a^{*}$-balance between redness (+) and greenness (-); $b^{*}$-balance between blueness (-) and yellowness (+); $\Delta E$-total color change index; $\mathrm{P}$-pellet; $\mathrm{S}$ - -snack; ${ }^{1}$-means of 10 replications; ${ }^{\mathrm{a}-\mathrm{k}}$-means indicated with similar letters in columns do not differ significantly at $\alpha=0.05$.

\subsection{Pasting Characteristics}

Peak viscosity $(\mathrm{PV})$ is closely related to the degree of starch granule damage, with severe damage directly leading to a higher peak viscosity [33]. The PV for pellets ranged from $110 \mathrm{mPas}$ (maximum additive content, extruded at $80 \mathrm{rpm}$ ) to $223.5 \mathrm{mPas}(2.5 \mathrm{~g} / 100 \mathrm{~g}$ additive, processed at maximum speed). In general, along with the increase in the fresh carrot pulp addition in the pellets, there was a decrease in the PV values compared to the control sample (processed at $60 \mathrm{rpm}$ ) at the level of 20.0 and $30.0 \mathrm{~g} / 100 \mathrm{~g}$ of this additive for all levels of additives at $80 \mathrm{rpm}$ and above $2.5 \mathrm{~g} / 100 \mathrm{~g}$, when the maximum rpm was applied during processing. An increase in pellet PV was observed from 0 to $5.0 \mathrm{~g} / 100 \mathrm{~g}$ of additive with increasing screw speed (Figure 4a).

The pellet PV was strongly negatively correlated with the amount of additive $(\mathrm{r}=-0.84)$, the AA and the $a^{*}$ color coordinate of pellets $(\mathrm{r}=-0.82$ and -0.83$)$, and strongly positively correlated with the VEI $(r=0.83), \mathrm{HPV}(\mathrm{r}=0.94), \mathrm{CPV}(\mathrm{r}=0.81)$ and BD $(r=0.97)$ of pellets, and PV $(r=0.84)$, HPV $(r=0.91), C P V(r=0.90)$ and SB $(r=0.83)$ of the expanded snacks. The lowest PV value was $85 \mathrm{mPas}$, and was observed for snacks made from pellets with the lowest PV. The highest PV value (201 mPas) was recorded for the snack with $5.0 \mathrm{~g} / 100 \mathrm{~g}$ pulp content processed at the lowest screw speed. For RTE snacks, the lowest PV values were recorded for samples produced at $80 \mathrm{rpm}$, with a fresh carrot level of $5.0 \mathrm{~g} / 100 \mathrm{~g}$ and above (Figure $5 \mathrm{a}$ ). The PV of snacks was strongly negatively correlated with the amount of additive $(\mathrm{r}=-0.94)$, the TPC of pellets $(\mathrm{r}=-0.86)$ and snacks $(\mathrm{r}=-0.85)$, the AA of pellets $(\mathrm{r}=-0.88)$ and snacks $(\mathrm{r}=-0.86)$, the $a^{*}$ coordinate of pellets $(\mathrm{r}=-0.91)$ and $a^{*}$ and $b^{*}$ of expanded snacks $(\mathrm{r}=-0.84$ and -0.85 , respectively). Negative correlation was noted between the PV of snacks and the VEI $(r=0.82)$, pellet lightness $(r=0.81)$, HPV $(r=0.91)$, CPV $(r=0.87)$, and snacks SB $(r=0.85)$. 

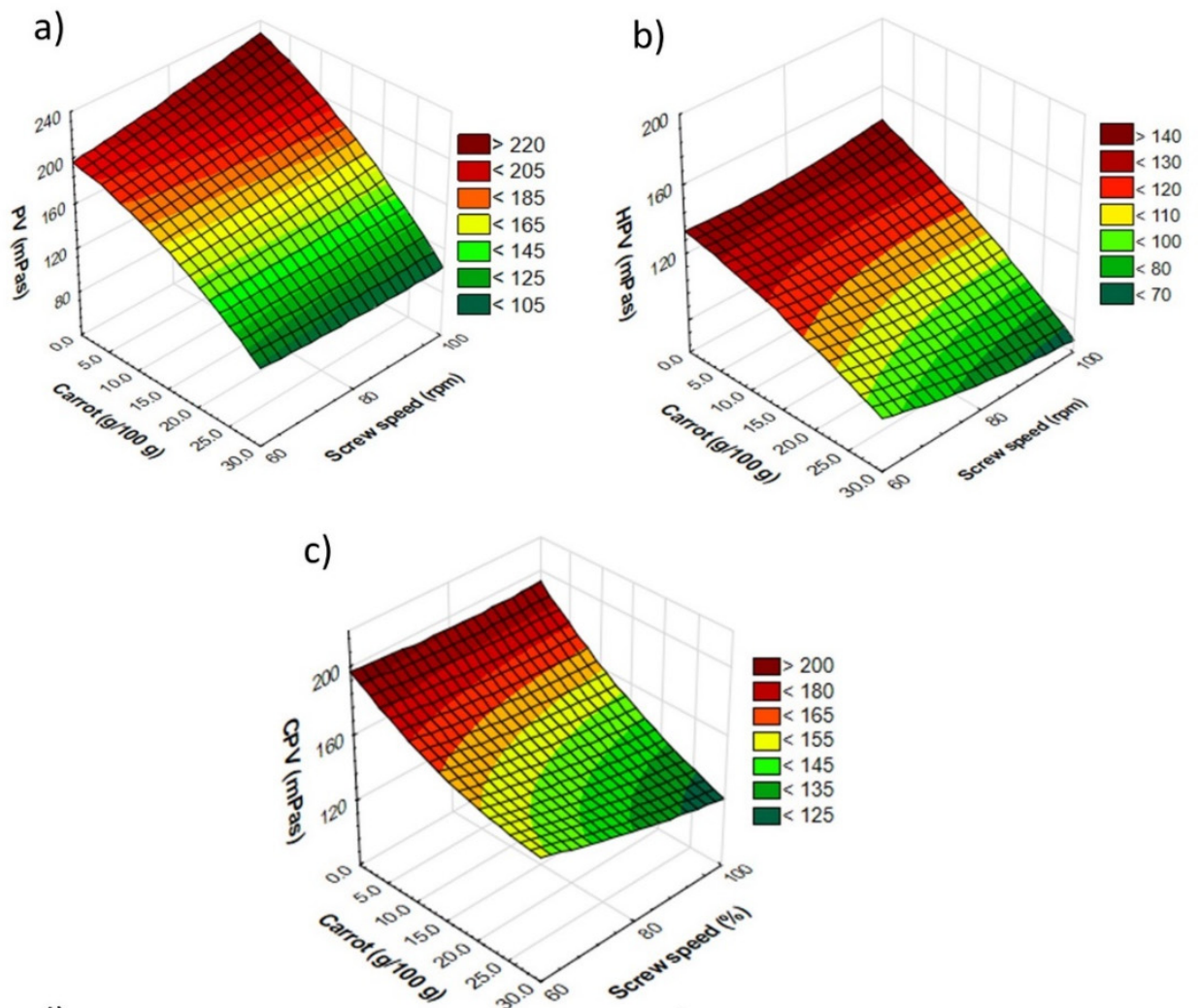

d)

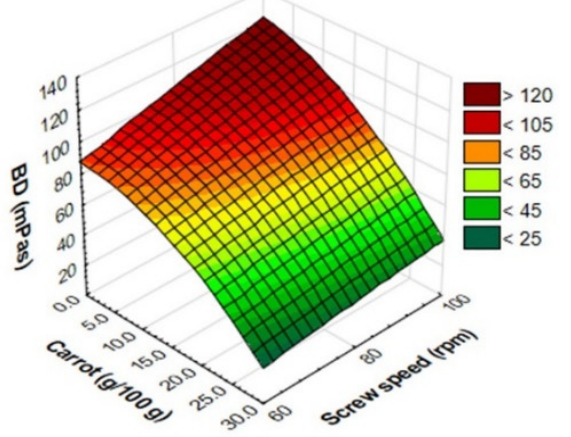

e)

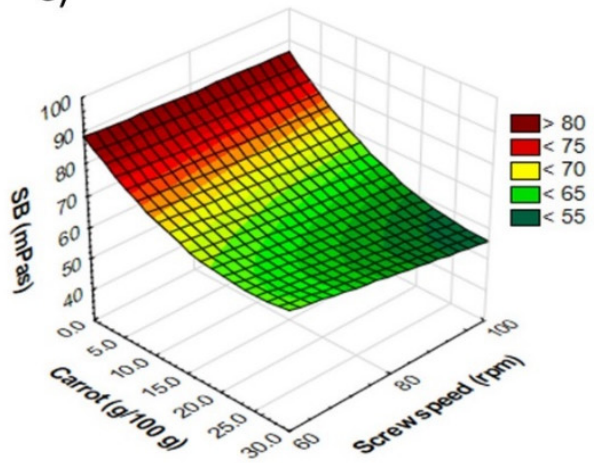

Figure 4. Results of pasting properties of extruded pellets enriched with fresh carrot pulp: (a) PVpeak viscosity, (b) HPV—hot paste viscosity, (c) CPV—cold paste viscosity, (d) BD—breakdown, (e) $\mathrm{SB}$ - setback.

Hot paste viscosity (HPV) indicates the sensitivity of the swollen starch granules to the shearing forces. The HPV values were within the range of from $77 \mathrm{mPas}$ (pellets with the maximum additive content, processed at the maximum rpm) to $163 \mathrm{mPas}$ (pellets with $10.0 \mathrm{~g} / 100 \mathrm{~g}$ addition, extruded at $60 \mathrm{rpm}$ ) for carrot-supplemented pellets (Figure $4 \mathrm{~b}$ ). $\mathrm{HPV}$ was also strongly positively correlated with pellet CPV $(\mathrm{r}=0.89), \mathrm{BD}(\mathrm{r}=0.86)$ and SB $(\mathrm{r}=0.81)$, and with supplemented snack HPV $(r=0.86)$ and CPV $(r=0.86)$. The HPV of microwave-expanded snacks was similar, and ranged from $65 \mathrm{mPas}$ (maximum additive content, extruded at $80 \mathrm{rpm}$ ) to $172 \mathrm{mPas}$ (control sample, made at $60 \mathrm{rpm}$ ) (Figure 5b). 

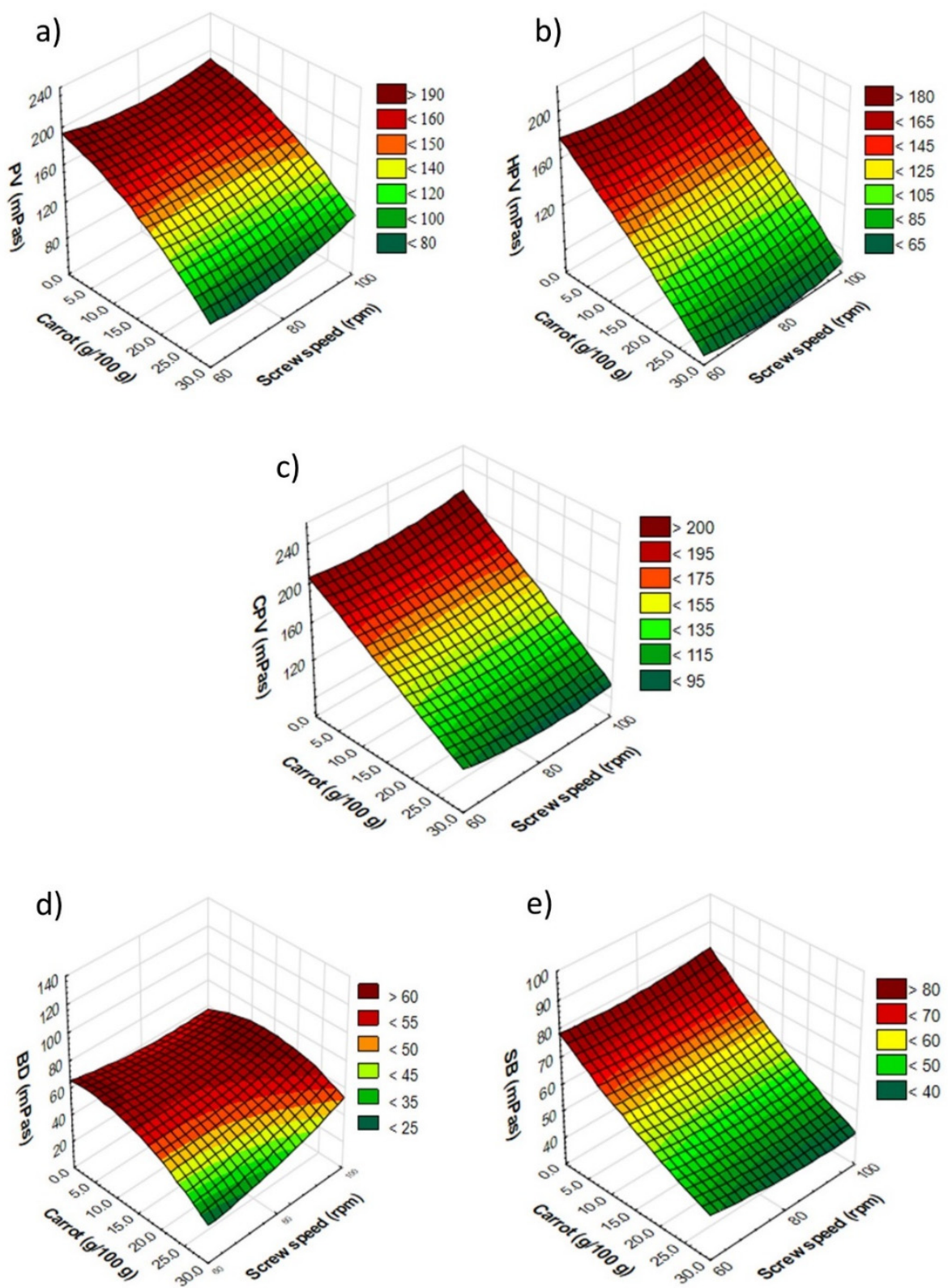

Figure 5. Results of pasting properties of expanded snacks enriched with fresh carrot pulp: (a) PVpeak viscosity, (b) HPV—hot paste viscosity, (c) CPV—cold paste viscosity, (d) BD—breakdown, (e) SB—setback.

In RTE directly expanded crisps, the HPV values of 18 to $38 \mathrm{mPas}$ were observed for white bean extrudates, and 27 to $59 \mathrm{mPas}$ for red bean extrudates [21]. The HPV of snacks was strongly negatively correlated with the amount of fresh carrot amount $(\mathrm{r}=-0.95)$, the TPC of pellets $(r=-0.89)$ and snacks $(r=-0.81)$, the AA of pellets $(r=-0.92)$ and snacks $(\mathrm{r}=-0.85)$, the $a^{*}$ coordinate of pellets $(\mathrm{r}=-0.92)$, and $a^{*}(\mathrm{r}=-0.87)$ and $b^{*}(\mathrm{r}=-0.85)$ of the expanded snacks. A positive correlation was found between the HPV of snacks and CPV $(r=0.87), B D(r=0.83)$ and SB $(r=0.82)$ of pellets, and between the HPV of snacks and CPV $(r=0.98)$ and SB $(r=0.94)$ of RTE snacks.

CPV denotes the final viscosity, indicating a tendency to the retrogradation of soluble amylose after cooling [34]. The CPV for pellets ranged from $122 \mathrm{mPas}$ (pellets with the lowest HPV) to $200 \mathrm{mPas}$ (pellets with a $2.5 \mathrm{~g} / 100 \mathrm{~g}$ addition to the recipe, extruded at $60 \mathrm{rpm})$. In the case of the CPV measured for pellets, a decrease was noticed with the increasing screw speed applied, except for the control sample and the sample with 
$20.0 \mathrm{~g} / 100 \mathrm{~g}$ of fresh carrot pulp in its composition (Figure 4c). The pellet CPV was strongly negatively correlated with the amount of additive $(\mathrm{r}=-0.84)$ and pellet and snack TPC ( $\mathrm{r}=-0.86$ and -0.85 , respectively), and the $a^{*}$ coordinate of snacks $(\mathrm{r}=-0.83)$. A positive correlation was observed between the CPV of pellets and their SB parameters $(r=0.97)$. The CPV for snacks ranged from $99.5 \mathrm{mPas}$ (snacks with the lowest PV and HPV) to $210 \mathrm{mPas}$ (control snacks, at $100 \mathrm{rpm}$ ). In the case of microwave-expanded snacks, the value of this parameter decreased above $40 \%$ for the samples with $20 \mathrm{~g} / 100 \mathrm{~g}$ of the vegetable component at all the rpms used, as compared to the control sample (Figure $5 c$ ). The snack CVP was strongly negatively correlated with the amount of additive $(r=-0.93)$, pellet TPC $(\mathrm{r}=-0.89)$, pellet and snack AA $\left(\mathrm{r}=-0.91\right.$ and -0.84 , respectively), the $a^{*}$ coordinate of pellets $(\mathrm{r}=-0.91)$, and $a^{*}(\mathrm{r}=-0.84)$ and $b^{*}$ of snacks $(\mathrm{r}=-0.80)$. A strong positive correlation was found between the CPV of snacks and the VEI $(r=0.80), \mathrm{BD}(\mathrm{r}=0.83)$, and the $\mathrm{SB}$ of pellets $(r=0.82)$ and snacks $(r=0.97)$.

Breakdown (BD) is related to the resistance to heating and shearing stress. It is also an indicator of swollen starch granule disintegration [35]. The lowest BD value was recorded for pellets $(18.5 \mathrm{mPas})$ and snacks $(19.5 \mathrm{mPas})$ with the maximum additive content, processed at the minimum rpm. In contrast, the highest value of BD was $132 \mathrm{mPas}$ and $88.5 \mathrm{mPas}$, respectively, for pellets with $2.5 \mathrm{~g} / 100 \mathrm{~g}$ of additive and snacks with a $20.0 \mathrm{~g} / 100 \mathrm{~g}$ addition of carrot pulp, both processed at the highest rpm. Microwave expansion decreased the BD value of carrot-supplemented snacks to a level of $10 \mathrm{~g} / 100 \mathrm{~g}$ at all rpms used, compared to the pellets (Figures $4 \mathrm{~d}$ and $5 \mathrm{~d}$ ). Moreover, pellet BD was strongly correlated with pellet bulk density $(\mathrm{r}=0.82)$ and with pellet VEI $(\mathrm{r}=0.84)$.

Setback (SB) shows the retrogradation behavior of starch gels. A high value of SB indicates a greater tendency to retrogradation, and thus translates into a greater probability of syneresis in the product [21]. The highest SB value was $90 \mathrm{mPas}$ (pellets with $2.5 \mathrm{~g} / 100 \mathrm{~g}$ additive content, extruded at $60 \mathrm{rpm}$ ) and $83 \mathrm{mPas}$ (control snack made at $100 \mathrm{rpm}$ ). While the lowest $\mathrm{SB}$ value was recorded for pellets and snacks with the maximum fresh carrot pulp content when processed at maximum screw speed (57 mPas and $42.5 \mathrm{mPas}$, respectively). Generally, microwave expansion resulted in lower SB values of the expanded snacks in relation to pellets (Figures $4 \mathrm{e}$ and $5 \mathrm{e}$ ). In our study, we noticed that the pellet SB was strongly negatively correlated with the amount of additive $(r=-0.84)$, the pellet and snack TPC $(r=-0.87$ and -0.81 , respectively), the AA of snacks $(r=-0.82)$, and the $a^{*}$ coordinate of the expanded snacks $(\mathrm{r}=-0.85)$. The SB of pellets also showed a strong positive correlation with the lightness of snacks $(r=0.83)$ and snack SB $(r=0.84)$. Similarly, the SB of carrot-supplemented snacks showed a strong negative correlation with the amount of additive $(\mathrm{r}=-0.93)$, the pellet and snack TPC $(\mathrm{r}=-0.92$ and -0.83 , respectively), pellet and snack $\mathrm{AA}\left(\mathrm{r}=-0.89\right.$ and -0.88 , respectively), $a^{*}$ coordinate of pellets $(\mathrm{r}=-0.90)$, and $a^{*}(\mathrm{r}=-0.84)$ and $b^{*}(\mathrm{r}=-0.81)$ of microwaved snacks.

\subsection{Texture of Extrudates and Final RTE Products}

Textural features play a key role in assessing snack quality and are also related to consumer acceptability [36]. Table 4 shows the values of the pellet cutting force and the results of texture tests for microwave-expanded snacks supplemented with fresh carrot pulp. Pellets with $2.5 \mathrm{~g} / 100 \mathrm{~g}$ of carrots in the composition produced at $80 \mathrm{rpm}$ showed the highest CF $(88.92 \mathrm{~N})$, while the lowest value of the tested parameter was characteristic for pellets $(15.26 \mathrm{~N})$ containing $30.0 \mathrm{~g} / 100 \mathrm{~g}$ of the additive and produced at $60 \mathrm{rpm}$. This was due to the disruption of the internal structure by the vegetable component. It was noticed that the extreme tests of $\mathrm{CF}$ of the pellets differed significantly between each type and the control pellets obtained at the same speed. 
Table 4. Cutting force of pellets and the texture profile of microwave-expanded snacks with the addition of fresh carrot pulp.

\begin{tabular}{|c|c|c|c|c|c|}
\hline \multirow[b]{2}{*}{$\begin{array}{l}\text { Amount of Carrot } \\
\qquad(\mathrm{g} / 100 \mathrm{~g})\end{array}$} & \multirow[b]{2}{*}{$\begin{array}{l}\text { Screw Speed } \\
\quad(\mathrm{rpm})\end{array}$} & \multirow[b]{2}{*}{$\begin{array}{c}\text { CF of Pellets }{ }^{1} \\
(\mathrm{~N})\end{array}$} & \multicolumn{3}{|c|}{ Texture of Expanded Snacks } \\
\hline & & & $\begin{array}{l}\mathrm{H}^{2} \\
(\mathrm{~N})\end{array}$ & $\begin{array}{c}\mathrm{CR}^{2} \\
(\mathrm{~N})\end{array}$ & $\begin{array}{l}F^{2} \\
(N)\end{array}$ \\
\hline \multirow{3}{*}{0} & 60 & $43.70 \pm 7.57 \mathrm{bcd}$ & $170.40 \pm 15.96^{a b c}$ & $10.47 \pm 1.50^{\mathrm{a}}$ & $26.07 \pm 4.96^{\mathrm{ab}}$ \\
\hline & 80 & $55.22 \pm 7.72 \mathrm{de}$ & $158.00 \pm 14.06^{\mathrm{abc}}$ & $34.97 \pm 5.62^{b}$ & $37.58 \pm 6.76^{b}$ \\
\hline & 100 & $66.38 \pm 7.96^{\text {efg }}$ & $195.40 \pm 19.17^{c}$ & $29.52 \pm 5.45^{\mathrm{ab}}$ & $36.30 \pm 6.12^{b}$ \\
\hline \multirow{3}{*}{2.5} & 60 & $75.64 \pm 5.95 \mathrm{gh}$ & $197.00 \pm 20.97 b c$ & $20.88 \pm 3.69 \mathrm{ab}$ & $23.88 \pm 5.66^{\mathrm{ab}}$ \\
\hline & 80 & $88.92 \pm 6.50^{\mathrm{h}}$ & $149.60 \pm 14.84^{\mathrm{abc}}$ & $18.34 \pm 3.81^{\mathrm{ab}}$ & $25.76 \pm 5.97^{\mathrm{ab}}$ \\
\hline & 100 & $83.28 \pm 8.46^{\text {gh }}$ & $162.20 \pm 18.41^{a b c}$ & $16.13 \pm 3.29 \mathrm{ab}$ & $26.34 \pm 3.90^{\mathrm{ab}}$ \\
\hline \multirow{3}{*}{5.0} & 60 & $56.06 \pm 6.40$ def & $150.40 \pm 14.39^{a b c}$ & $18.51 \pm 4.93^{\mathrm{ab}}$ & $26.52 \pm 4.81^{\mathrm{ab}}$ \\
\hline & 80 & $43.64 \pm 6.61 \mathrm{bcd}$ & $136.16 \pm 17.41^{\mathrm{ab}}$ & $13.81 \pm 2.66^{\mathrm{ab}}$ & $19.61 \pm 2.37^{a b}$ \\
\hline & 100 & $45.56 \pm 3.88^{\mathrm{bcd}}$ & $109.40 \pm 4.45^{\mathrm{a}}$ & $21.38 \pm 5.24 \mathrm{ab}$ & $25.56 \pm 4.94^{\mathrm{ab}}$ \\
\hline \multirow{3}{*}{7.5} & 60 & $35.00 \pm 5.18^{b c}$ & $109.98 \pm 16.38^{a}$ & $16.26 \pm 2.02^{\mathrm{ab}}$ & $19.00 \pm 3.46^{\mathrm{ab}}$ \\
\hline & 80 & $53.18 \pm 5.69$ de & $107.38 \pm 15.85^{a}$ & $18.82 \pm 2.47^{a b}$ & $23.62 \pm 4.45^{\mathrm{ab}}$ \\
\hline & 100 & $53.64 \pm 7.16^{\text {de }}$ & $126.82 \pm 12.90^{\mathrm{ab}}$ & $13.57 \pm 2.75^{a b}$ & $14.67 \pm 2.95^{\mathrm{a}}$ \\
\hline \multirow{3}{*}{10.0} & 60 & $45.74 \pm 5.57^{\mathrm{bcd}}$ & $192.00 \pm 28.01^{a b c}$ & $17.55 \pm 4.10^{\mathrm{ab}}$ & $22.77 \pm 2.26^{\mathrm{ab}}$ \\
\hline & 80 & $29.42 \pm 4.22^{\mathrm{ab}}$ & $164.60 \pm 19.21^{a b c}$ & $18.67 \pm 4.59^{\mathrm{ab}}$ & $25.43 \pm 6.69^{a b}$ \\
\hline & 100 & $55.48 \pm 6.16^{\text {de }}$ & $157.58 \pm 20.47^{a b c}$ & $21.50 \pm 5.48^{a b}$ & $28.72 \pm 5.91^{a b}$ \\
\hline \multirow{3}{*}{20.0} & 60 & $32.64 \pm 5.82 \mathrm{bc}$ & $168.20 \pm 23.68^{a b c}$ & $24.50 \pm 3.5^{\mathrm{ab}}$ & $25.48 \pm 4.46^{\mathrm{ab}}$ \\
\hline & 80 & $73.12 \pm 6.94^{\mathrm{fgh}}$ & $151.20 \pm 37.98^{a b c}$ & $18.49 \pm 2.45^{\mathrm{ab}}$ & $18.94 \pm 2.28^{a b}$ \\
\hline & 100 & $81.24 \pm 9.28 \mathrm{gh}$ & $143.40 \pm 32.32^{a b c}$ & $17.17 \pm 5.9^{a b}$ & $24.25 \pm 4.23^{\mathrm{ab}}$ \\
\hline \multirow{3}{*}{30.0} & 60 & $15.26 \pm 3.20^{\mathrm{a}}$ & $99.92 \pm 20.42^{\mathrm{a}}$ & $15.88 \pm 4.73^{\mathrm{ab}}$ & $16.23 \pm 4.48^{\mathrm{ab}}$ \\
\hline & 80 & $33.56 \pm 6.33 b c$ & $161.40 \pm 30.76^{\mathrm{abc}}$ & $16.26 \pm 4.9^{\mathrm{ab}}$ & $18.45 \pm 4.09^{\mathrm{ab}}$ \\
\hline & 100 & $47.16 \pm 7.19^{\mathrm{cd}}$ & $141.20 \pm 32.93^{a b c}$ & $16.64 \pm 5.99 \mathrm{ab}$ & $23.42 \pm 4.14^{\mathrm{ab}}$ \\
\hline
\end{tabular}

$\mathrm{CF}$-cutting force; H-hardness; CR-crispness; FR-fracturability; P-pellet; S-snack; ${ }^{1}$-means of 10 replications; ${ }^{2}$-means of 5 replications; ${ }^{\mathrm{a}-\mathrm{h}}$-means indicated with similar letters in columns do not differ significantly at $\alpha=0.05$.

Snacks expanded from these pellets also showed the lowest hardness (99.92 N) via the Kramer cell test. In addition, we saw that there was a positive correlation between the CF and the $L^{*}(\mathrm{r}=0.63)$ color coordinate. The pellets made at $100 \mathrm{rpm}$ from the control recipe, and the samples with $2.5 \mathrm{~g} / 100 \mathrm{~g}$ of the additive extruded at $60 \mathrm{rpm}(195.40 \mathrm{~N}$ and $197.00 \mathrm{~N}$, respectively) were the hardest. In a study of snacks with the addition of apple pomace above $28 \%$, a decrease in the diameter of the air cells and an increase in the hardness of the formed snack were noted [37]. In our case, decreasing pellet hardness was the result of the decreasing amount of starch undergoing gelatinization, in favor of fresh carrot pulp. The extreme values of crispness were observed during the testing of the control sample. Here, the minimum value was observed at the lowest rpm $(10.47 \mathrm{~N})$-indicating a good crispness value in the expanded snacks. Snacks made from the control blend were characterized by the highest crispness, as well as the fracturability, when extruded at $80 \mathrm{rpm}(34.97 \mathrm{~N}$ and $37.58 \mathrm{~N})$ and $100 \mathrm{rpm}(29.52 \mathrm{~N}$ and $36.30 \mathrm{~N})$, respectively. After microwave expansion, snacks supplemented with $7.5 \mathrm{~g} / 100 \mathrm{~g}$ of fresh carrot pulp in the composition, processed at $100 \mathrm{rpm}$, showed the minimum fracture force value. Nevertheless, all snacks expanded by microwaves showed a narrow range of texture profile result variability, especially $C R$ and FR, with insignificant effects of both the carrot pulp amount and the screw speed applied. Additionally, there was a positive correlation between the crispness and fracturability of snacks $(r=0.77)$. The higher amount of carrot in the recipe had an unambiguous effect on the crispness of RTE snacks.

\subsection{Principal Component Analysis (PCA)}

Principal component analysis (PCA) is one of the most common statistical data reduction methods. Principal component analysis (Figure 6) was carried out in order to identify 
the differences in pellets and microwave-expanded snacks supplemented with fresh carrot pulp, processed at various rpm. PCA made it possible to select the discriminants that had the greatest impact on the differences between samples. The analysis itself consists of determining the component variables that are a linear combination of many examined features. The evaluation of the PCA graph (Figure 6a) shows that there is a strong but negative correlation between the parameters from the yellow ellipse and the parameters from the red ellipse. These parameters have the greatest influence on the system variability and describe the PC1 parameter. In the case of pellets, the first component of PC1 explained $65.09 \%$ of the variability of the results, and is positively related to TPC, AA, and the pellet $a^{*}$ and $b^{*}$ color coordinates. In contrast, it was negatively related to the BBD, the VEI, the lightness and the parameters describing pasting properties. In turn, the WAI and WSI are negatively correlated to each other. They also have a significant impact on the system variability and describe the second main component of PC2 in $12.27 \%$ of the results (highly negatively related to the WAI, and positively related to pellet WSI). There is no correlation between WAI and the parameters contained in the yellow and red ellipses. There is also a weak positive correlation between the WSI and the parameters in the yellow ellipse, and a weak negative correlation between the WSI and the parameters in the red ellipse. Additionally, there is a negative correlation between the WSI and CF. The location of the samples next to each other on the chart (Figure $6 \mathrm{~b}, \mathrm{~d}$ ) shows that the features are similar, and the distance between them indicates the nature of the differences. After placing the samples in the vicinity of the first two components (Figure 6b), it is evident that the samples differ from each other in terms of the carrot addition level. Moreover, significant differences can be seen at the supplementation levels of 20.0 and $30.0 \mathrm{~g} / 100 \mathrm{~g}$ in relation to the lower levels of fortification. From this graph, it can be concluded that the first major component describes the system variability and determines the content of the additive to $65.09 \%$. In the case of microwave-expanded snacks, the first component (Figure 6c) explains 55.86\% of the variability of the results, and is positively related to TPC, AA, color coordinates $a^{*}$ and $b^{*}$ values, and negatively related to the snack VEI, $L^{*}$ and PV, HPV, CPV and SB. We can also conclude that there is a strong but negative correlation between the parameters from the yellow ellipse and the parameters from the red ellipse. The parameters contained in these ellipses have the greatest influence on the system variability when assessing the expanded snacks.

The second component accounts for $16.45 \%$ of the variability of the results and is highly negatively correlated with the expanded snack WAI and BD. Placing snacks results in the vicinity of the examined components (Figure 6d) showed generally similar relationships, as in the case of pellets- that snacks differ from each other with the increase in vegetable addition. However, greater differences were noticed between snacks containing 20.0 and $30.0 \mathrm{~g} / 100 \mathrm{~g}$ of additive than between the corresponding pellets. From this graph, it can be concluded that the first major component describes the system variability and determines the effect of the vegetable additive to $55.86 \%$. Here, PC1 takes positive values when the amount of fresh carrot pulp increases in the recipe. 
a)

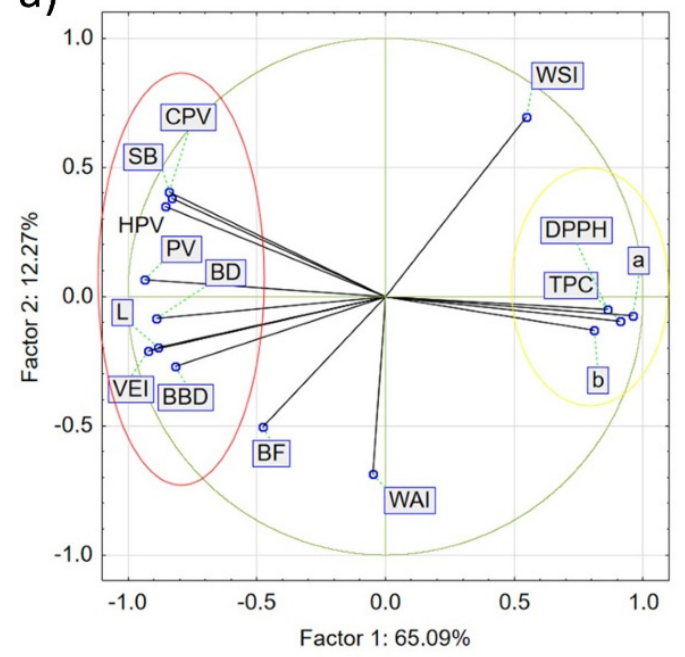

c)

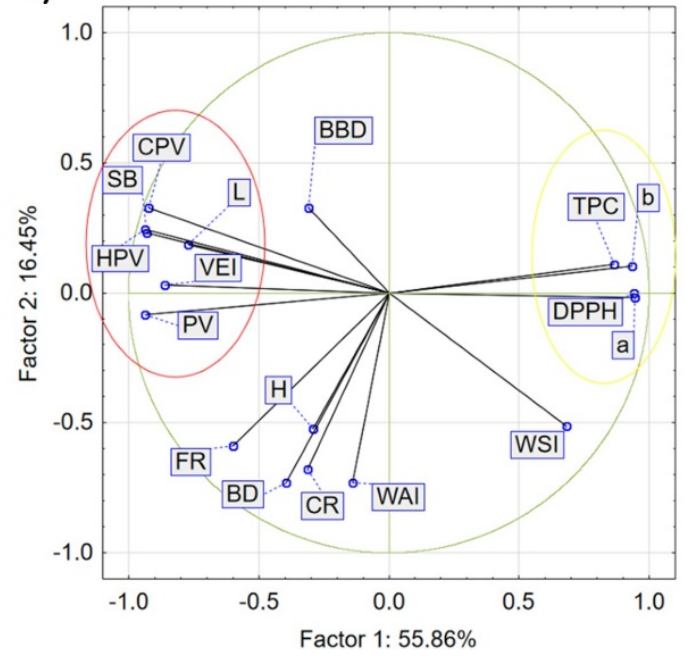

b)

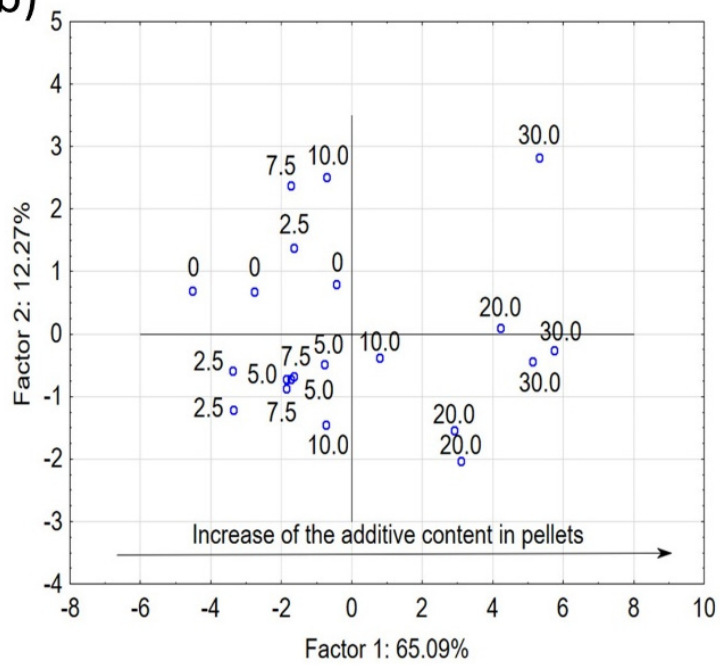

d)

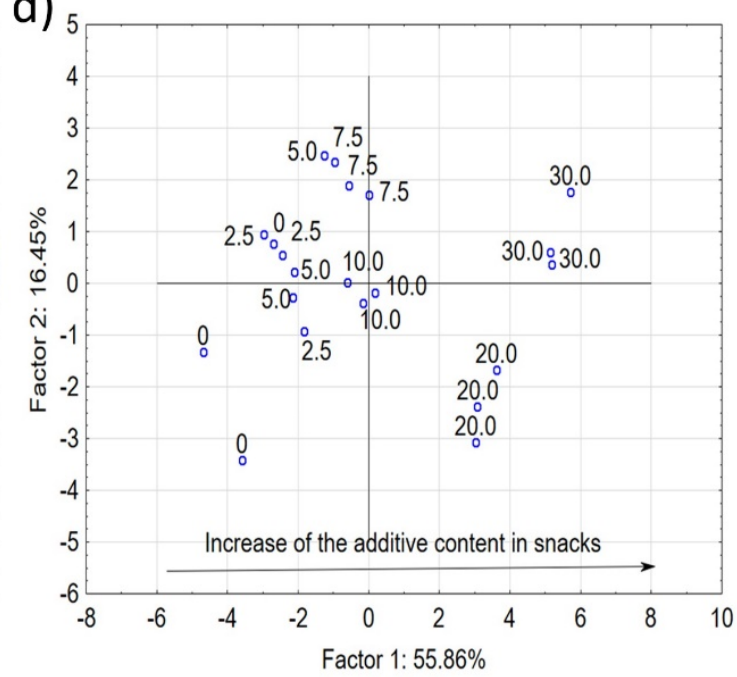

Figure 6. Analysis of principal components (PCA) of pellet (a) and snack (c) features and objects, as well as pellets (b) and snacks (d) in the space of the first two major components: TPC—-total phenolic content; DPPH—antioxidant activity; BBDbulk density; EI-volumetric expansion index; WAI—water absorption index; WSI-water solubility index; $L^{*}$ - lightness; $a^{*}$-balance between redness $(+)$ and greenness (-); $b^{*}$-balance between blueness $(-)$ and yellowness (+); PV—peak viscosity; HPV—hot paste viscosity; CPV—cold paste viscosity; BD—breakdown; SB—setback; CF—cutting force; H—hardness; CR—crispness; FR—fracturability; Factor 1-first component; Factor 2—second component; 0-30—amount of fresh carrot pulp (g/100 g).

\section{Conclusions}

The obtained results show that it is possible to acceptably enrich extruded snack pellets as half products with fresh carrot pulp, to the amount of up to $30.0 \mathrm{~g} / 100 \mathrm{~g}$. The RTE snacks obtained by microwave expansion of these pellets were characterized by a significant increase in the total content of polyphenols and by higher antioxidant activity, lower bulk density, higher WSI value, increased lightness, and decreased setback as compared to the pellets. The main impact on the differences between pellets and expanded snacks is shown by the measurements of the total polyphenol content, antioxidant activity, volumetric expansion index, color determinants and pasting properties (for snacks, except for breakdown). To sum up, a new type of microwave-expanded snack supplemented with the addition of fresh carrot pulp can be a high-quality, nutritionally valuable and fat-free alternative to the typically deep-fried crisps. Moreover, the knowledge from PCA analysis about the mutual influence of supplementation and screw speed during processing can be 
helpful in the design of new products processed by extrusion-cooking. The application of fresh vegetable material could not only be a valuable way to save water used in production and the energy needed for the drying process, but also have a positive effect on the material nutritional value, as compared to dried plant matter.

Author Contributions: Preparation of manuscript, K.L. and A.W.; conceptualization, K.L. and A.W.; investigation, K.L. and A.W.; methodology, K.L., A.W. and M.G.; supervision, A.W.; writing-original draft, K.L. and A.W.; writing—review and editing, A.W. and M.G. All authors have read and agreed to the published version of the manuscript.

Funding: This research received no external funding.

Institutional Review Board Statement: Not applicable.

Informed Consent Statement: Not applicable.

Data Availability Statement: The data presented in this study are available on request from the corresponding author.

Conflicts of Interest: The authors declare no conflict of interest.

\section{References}

1. Ozturk, O.K.; Takhar, P.S. Physical and viscoelastic properties of carrots during drying. J. Texture Stud. 2019, 51, 532-541. [CrossRef] [PubMed]

2. Durazzo, A. Study approach of antioxidant properties: Updated and considerations. Foods 2017, 6, 17. [CrossRef] [PubMed]

3. Santini, A.; Tenore, G.C.; Novellino, E. Nutraceuticals: A paradigm of proactive medicine. Eur. J. Pharm. Sci. 2017, 1, 53-61. [CrossRef] [PubMed]

4. Li, Y.O.; Komarek, A.R. Dietary fibre basics: Health, nutrition, analysis, and applications. Food Qual. Saf. 2017, 1, 47-59. [CrossRef]

5. Bozalan, N.K.; Karadeniz, F. Carotenoid profile, total phenolic content, and antioxidant activity of carrots. Int. J. Food Prop. 2011, 14, 1060-1068. [CrossRef]

6. Hedrén, E.; Diaz, V.; Svanberg, U. Estimation of carotenoid accessibility from carrots determined by an in vitro digestion method. Eur. J. Clin. Nutr. 2002, 56, 425-430. [CrossRef]

7. Klein, C.; Rodriguez-Concepcion, M. Carotenoids in Carrot. In Pigments in Fruits and Vegetables; Chen, C., Ed.; Springer: New York, NY, USA, 2015; pp. 217-228.

8. Da Silva Dias, J.C. Nutritional and health benefits of carrots and their seed extracts. J. Food Nutr. 2014, 5, 2147-2156. [CrossRef]

9. Conner, T.S.; Brookie, K.L.; Richardson, A.C.; Polak, M.A. On carrots and curiosity: Eating fruit and vegetables is associated with greater flourishing in daily life. Brit. J. Health Psychol. 2015, 20, 413-427. [CrossRef]

10. Wójtowicz, A.; Zalewska-Korona, M.; Jabłońska-Ryś, E.; Skalicka-Woźniak, K.; Oniszczuk, A. Chemical characteristics and physical properties of functional snacks enriched with powdered tomato. Polish J. Food Nutr. Sci. 2018, 68, 251-261. [CrossRef]

11. Luo, S.; Chan, E.; Masatcioglu, M.T.; Erkinbaev, C.; Paliwal, J.; Koksel, F. Effects of extrusion conditions and nitrogen injection on physical, mechanical, and microstructural properties of red lentil puffed snacks. Food Bioprod. Process. 2020, 121, 143-153. [CrossRef]

12. Krau, S.; Schuchmann, H.P.; Gaukel, V. Factors influencing the microwave-induced expansion of starch-based extruded pellets under vacuum. J. Food Process Eng. 2014, 37, 264-272. [CrossRef]

13. Lisiecka, K.; Wójtowicz, A. Possibility to save water and energy by application of fresh vegetables to produce supplemented potato-based snack pellets. Processes 2020, 8, 153. [CrossRef]

14. Lisiecka, K.; Wójtowicz, A.; Bouasla, A.; Kasprzak, K. Design of new gluten-free extruded rice snack products supplemented with fresh vegetable pulps: The effect on processing and functional properties. Int. Agrophys. 2021, 35, 41-60. [CrossRef]

15. Singleton, V.; Orthofer, R.; Lamuela-Raventós, R.M. Analysis of total phenols and other oxidation substrates and antioxidants by means of Folin-Ciocalteu reagent. Method. Enzymol. 1999, 299C, 152-178.

16. Lisiecka, K.; Wójtowicz, A.; Dziki, D.; Gawlik-Dziki, U. The influence of Cistus incanus L. leaves on wheat pasta quality. J. Food Sci. Technol. 2019, 56, 4311-4322. [CrossRef] [PubMed]

17. Oniszczuk, A.; Olech, M.; Oniszczuk, T.; Wojtunik-Kulesza, K.; Wójtowicz, A. Extraction methods, LC-ESI-MS/MS analysis of phenolic compounds and antiradical properties of functional food enriched with elderberry flowers or fruits. Arab. J. Chem. 2016, 12, 4719-4730. [CrossRef]

18. Blois, M.S. Antioxidant determinations by the use of a stable free radical. Nature 1958, 181, 1199-1200. [CrossRef]

19. Lisiecka, K.; Wójtowicz, A. The influence of fresh kale addition on selected properties of corn snacks. Int. J. Food Eng. 2019, 15, 20180319. [CrossRef]

20. Jozinović, A.; Ačkar, D.; Jokić, S.; Babić, J.; Balentić, J.P.; Banožić, M.; Šubarić, D. Optimisation of extrusion variables for the production of corn snack products enriched with defatted hemp cake. Czech J. Food Sci. 2017, 35, 507-516. 
21. Mitrus, M.; Wójtowicz, A.; Kocira, S.; Kasprzycka, A.; Szparaga, A.; Oniszczuk, T.; Combrzyński, M.; Kupryaniuk, K.; Matwijczuk, A. Effect of extrusion-cooking conditions on the pasting properties of extruded white and red bean seeds. Int. Agrophys. 2020, 34, 25-32. [CrossRef]

22. Shah, F.U.H.; Sharif, M.K.; Butt, M.S.; Shahid, M. Development of protein, dietary fiber, and micronutrient enriched extruded corn snacks. J. Texture Stud. 2017, 48, 221-230. [CrossRef]

23. Hayat, K.; Zhang, X.; Chen, H.; Xia, S.; Jia, C.; Zhong, F. Liberation and separation of phenolic compounds from citrus mandarin peels by microwave heating and its effect on antioxidant activity. Sep. Purif. Technol. 2010, 73, 371-376. [CrossRef]

24. Wataniyakul, P.; Pavasant, P.; Goto, M.; Shotipruk, A. Microwave pretreatment of defatted rice bran for enhanced recovery of total phenolic compounds extracted by subcritical water. Bioresour. Technol. 2012, 124, 18-22. [CrossRef] [PubMed]

25. Parcheta, M.; Świsłocka, R.; Orzechowska, S.; Akimowicz, M.; Choińska, R.; Lewandowski, W. Recent developments in effective antioxidants: The structure and antioxidant properties. Materials 2021, 14, 1984. [CrossRef] [PubMed]

26. Ruiz-Armenta, X.A.; Zazueta-Morales, J.D.J.; Delgado-Nieblas, C.I.; Carrillo-López, A.; Aguilar-Palazuelos, E.; CamachoHernández, I.L. Effect of the extrusion process and expansion by microwave heating on physicochemical, phytochemical, and antioxidant properties during the production of indirectly expanded snack foods. J. Food Process. Preserv. 2019, 43 , e14261. [CrossRef]

27. Sun, Y.; Muthukumarappan, K. Changes in functionality of soy-based extrudates during single-screw extrusion processing. Int. J. Food Prop. 2002, 5, 379-389. [CrossRef]

28. Pardhi, S.D.; Singh, B.; Nayik, G.A.; Dar, B.N. Evaluation of functional properties of extruded snacks developed from brown rice grits by using response surface methodology. J. Saudi Soc. Agric. Sci. 2019, 18, 7-16. [CrossRef]

29. Oikonomou, N.A.; Krokida, M.K. Literature data compilation of WAI and WSI of extrudate food products. Int. J. Food Prop. 2011, 14, 199-240. [CrossRef]

30. Da Silva, M.C.; De Carvalho, C.W.P.; Andrade, C.T. The effects of water and sucrose contents on the physicochemical properties of non-directly expanded rice flour extrudates. Ciênc. Tecnol. Aliment. 2009, 29, 661-666. [CrossRef]

31. Emran, S.; Nawade, B.; Yahyaa, M.; Jackline, A.N.; Dorothea, T.; Eizenberg, H.; Mwafaq, I. Broomrape infestation in carrot (Daucus carota): Changes in carotenoid gene expression and carotenoid accumulation in the parasitic weed Phelipanche aegyptiaca and its host. Sci. Rep. 2020, 10, 1-10. [CrossRef]

32. Sawant, A.A.; Thakor, N.J.; Swami, S.B.; Divate, A.D. Physical and sensory characteristics of Ready-to-Eat food prepared from finger millet based composite mixer by extrusion. E-J. CIGR 2013, 15, 100-105.

33. Adepehin, J.O. Microbial diversity and pasting properties of finger millet (Eleusine coracana), pearl millet (Pennisetum glaucum) and sorghum (Sorghum bicolor) sourdoughs. Food Biosci. 2020, 37, 100684. [CrossRef]

34. Lopes, L.C.M.; Batista, K.A.; Fernandes, K.F.; Santiago, R.A.C. Functional, biochemical and pasting properties of extruded bean (Phaseolus vulgaris L.) cotyledons. Int. J. Food Sci. Technol. 2012, 47, 1859-1865. [CrossRef]

35. Valdez-Arana, J.C.; Steffolani, M.E.; Repo-Carrasco-Valencia, R.; Pérez, G.T.; Condezo-Hoyos, L. Physicochemical and functional properties of isolated starch and their correlation with flour from the Andean Peruvian quinoa varieties. Int. J. Biol. Macromol. 2020, 147, 997-1007. [CrossRef]

36. Wójtowicz, A.; Kolasa, A.; Mościcki, L. Influence of buckwheat addition on physical properties, texture and sensory characteristics of extruded corn snacks. Polish J. Food Nutr. Sci. 2013, 63, 239-244. [CrossRef]

37. Karkle, E.; Alavi, S.; Dogan, H. Cellular architecture and its relationship with mechanical properties in expanded extrudates containing apple pomace. Food Res. Int. 2012, 46, 10-21. [CrossRef] 